Stella Kasoulides Paulson

\title{
When It Comes to General Anti-Avoidance Rules, is Broader Better?
}

LLM RESEARCH PAPER

LAWS 516: TAXATION, INTERNATIONAL AND

DOMESTIC

\section{FACULTY OF LAW}

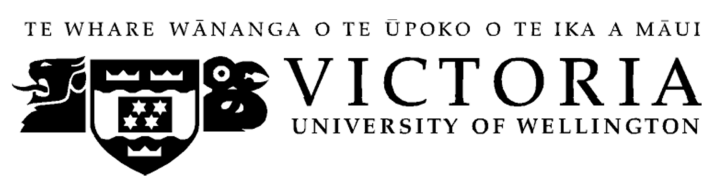

2013 


\section{Contents}

LLM RESEARCH PAPER IAWS 516: Taxation, international and domestic 1

FACULTY OF LAW 2013

Contents 2

Abstract 4

Word length 4

I Introduction $\mathbf{5}$

A The Comparators 6

$\begin{array}{ll}\text { II Background } & \mathbf{7}\end{array}$

A The Rule of Law and Certainty 7

$B \quad$ Uncertainty Is Necessary in the GAAR Context 9

C Definitions 11

$D$ The Role of a GAAR 13

III Drawing the Line 14

A Introduction 14

B Basic Characteristics of All GAARs 14

IV Abuse and Misuse Requirements 16

C Canada-The Comparison 16

D The Approach 17

V Central Objection to the Approach in Canada and New

Zealand: $\quad 21$

A The Objection 21

$B$ The limits of the purposive approach to statutory

interpretation $\quad 22$

C The Ramsay Principle versus a GAAR analysis 24

VI The United Kingdom - An Enlightened GAAR? 27

A The Aaronson Report 28

B The Double Reasonableness Test 31

VII The Broadened Inquiry - Factors Courts Consider 33

A How the Inquiry Is Broadened 34

1 A purpose of tax avoidance becomes justifiably relevant 34

2 Indicative Factors Considered Under a GAAR Analysis 35 
B How Does the GAAR Allow For Factors to Be Considered? 35

$C$ How the factors are used to draw the line

1 Objection to considering factors when determining purpose

VIII The Danger of Enumeration

A Factors - Should They Be Legislatively Enacted or Left to the Courts Discretion?

1 Objection to non-legislated factors: 42

2 Enumeration does not create more certainty. 43

$B$ Enumeration is Undesirable 44

1 Judicial Discretion is not so offensive as it seems: 44

2 The Main Point: General anti-avoidance rules are broad on purpose. $\quad 46$

3 The Dangers of Enumeration: 47

Expressio Unius or Implied Exclusion $\quad 47$

C Enumeration Gone Wrong - Identifying a Counterfactual 49

IX Conclusion $\quad 55$

$\begin{array}{lll}\text { X BIBLIOGRAPHY } & \mathbf{5 7}\end{array}$

I. Speeches 66 


\section{Abstract}

This paper examines the proposition that general anti-avoidance rules achieve their purpose better when drafted in broad terms. Several jurisdictions have included misuse and abuse requirements in their GAARs in order to provide certainty and a high threshold for the GAAR's operation. Others have enumerated their GAAR to add precision and certainty to its terms. While misuse and abuse requirements and enumeration have the appearance of adding precision to an uncertain area of law, in practice this is doubtful. The general anti-avoidance provisions of four jurisdictions are compared, namely Australia, Canada, New Zealand and the United Kingdom. This article comes to two conclusions; that adding a misuse and abuse requirement to a GAAR does not significantly alter the substance of the inquiry; and that adding further details and precisions to a GAAR does more harm than good. These two conclusions promote the main proposition of this paper, that general anti-avoidance rules work best when drafted in broad terms. The international trend is heading towards more enumerated general anti-avoidance

provisions; this paper aims to counter some of the arguments in favour of that trend.

\section{Word length}

The text of this paper (excluding, table of contents, footnotes and bibliography) comprises approximately 13, 000 words.

\section{Subjects and Topics}

Tax Law - Tax Avoidance - General Anti-Avoidance Rules - 


\section{Introduction}

The United Kingdom enacted a statutory general anti-avoidance rule, commonly known as a GAAR, on the $17^{\text {th }}$ July 2013 , just before this paper was written. The UK government took this step years, even decades, after many other countries and in so doing had the benefit of learning from international experience. It should therefore be telling that the UK chose specifically not to introduce a broad spectrum GAAR but rather a narrow, targeted, anti abusive avoidance rule. The United Kingdom also chose to include a list of legislatively enacted criteria for the courts to consider in their determination of abusive avoidance, rather than opting for more limited guidance as in New Zealand and Canada. In so drafting their GAAR, the government of the day surely had in mind some practical end different from that achieved in jurisdictions with a broadly drafted GAAR.

The function of a GAAR is to provide an all-encompassing provision to shield tax statutes from contrived and aggressive arrangements aimed at exploiting loopholes in a tax regime. A GAAR applies where an arrangement has satisfied the technical requirements of the law but is nonetheless an unacceptable arrangement. Because it is impossible for a parliament to predict every arrangement that a taxpayer might possibly carry out, it is necessary to have a broadly drafted rule, able to apply to innumerable situations concerning a multitude of highly technical specific provisions. However, there are several considerations which can pressure a government to enact a less broad GAAR than otherwise. The desire for certainty in the law is a compelling force that can influence a government to add precision and extra requirements to their GAAR.

This paper aims to examine what practical difference, if any, there is between the application in practice of a narrow antiabuse rule, a detailed rule, and a general general anti-avoidance rule. 
The comparisons in this paper serve to demonstrate two central points which in turn both contribute to one main proposition.

1 An abuse/misuse requirement does not fundamentally alter the material inquiry under a GAAR; this is shown by comparing the approach of the courts under an anti-abuse rule to the approach under a broadly drafted rule

2 Adding detail to a GAAR also does not fundamentally alter the inquiry and actually does more harm than good; this is shown by comparing the experience of Australia, whose provision is considerably detailed, to those jurisdictions with more broadly drafted GAARs such as New Zealand and Canada. This comparison also highlights some of the problems Australia has faced with their GAAR as a result of attempting to add precision to its terms.

These two points both contribute to the central proposition of this paper that GAARs work best when drafted in broad terms.

\section{A The Comparators}

This paper compares four jurisdictions, namely, Australia, Canada New Zealand and the United Kingdom. All four of these jurisdictions enjoy a shared background, as part of the commonwealth and all operating as Common Law systems. Their shared background makes these jurisdictions make ideal comparators for this paper, as each originally adopted the Duke of Westminster principle, ${ }^{1}$ that taxpayers are free to construct their affairs to minimise tax. In this way, the tax avoidance jurisprudence in each jurisdiction is evolved from similar beginnings. ${ }^{2}$ Each jurisdiction has a statutory anti-avoidance provision, however every one of those provisions is drafted in

${ }^{1}$ Inland Revenue Commissioners v Duke of Westminster HL [1936] AC 1; applied in Australia: Anderson v Commissioner of Taxes (Vic) (1937) 57 CLR 233; New Zealand Commissioner of Inland Revenue v Europa Oil (NZ) Ltd [1971] NZLR 641; and Canada Stubart Investments Ltd v The Queen [1984] 1 SCR 536.

${ }^{2}$ Chris Atkinson "General Anti-Avoidance Rules: Exploring the Balance Between the Taxpayer's Need For Certainty and the Government's Need to Prevent Tax Avoidance" (2012) 14 Journal of Australian Taxation 1 at [7]. 
different terms. The relevant provisions are; Part IVA in Australia, ${ }^{3}$ s 245 in Canada, ${ }^{4}$ s BG 1 and YA 1 in New Zealand, and the $\mathrm{s} 207$ in the United Kingdom. ${ }^{6}$

This paper undertakes several comparisons to demonstrate the two main points outlined above which contribute to the proposition that a GAAR achieves its purpose better when drafted in broad terms. The Canadian GAAR, which has been in place since 1988, contains a misuse and abuse requirement and has been subject to a great deal of judicial analysis. New Zealand's provision is compared with Canada's to examine whether a misuse/abuse requirement fundamentally alters the working of a GAAR. While the United Kingdom GAAR also contains a misuse/abuse requirement it had not been subject to any judicial analysis when this paper was written and thus its practical application can only be examined hypothetically. The comparisons here demonstrate that in substance the application of a broad GAAR is largely the same as a targeted anti-abuse GAAR because of the courts' processes of interpretation and application.

The current Australian GAAR has been in place since 1981, and in appearance is very different to the others, simply because of its length. The Australian GAAR is a detailed provision, comparing it to Canada and New Zealand's GAARs reveals that in this context detail brings complexity and that complexity can have undesirable consequences.

\section{Background}

\section{A The Rule of Law and Certainty}

The rule of law is a central pillar of democratic, fair and just government. ${ }^{7}$ As such, arguments founded upon upholding the

\footnotetext{
${ }^{3}$ Part IVA Income Tax Assessment Act 1936 (Cth) (Austl.);

${ }^{4}$ s 245 Income Tax Act RSC 1985, c. 1 (5th Supp.), as amended, (Can.);

${ }^{5}$ New Zealand s BG 1 and YA 1 Income Tax Act 2007 (NZ); and

${ }^{6}$ United Kingdom s 207 Finance Act 2013 (UK).
} 
rule of law carry great weight and emotive prominence in any debate. While the exact content of the rule of law is subject to ongoing debate, the idea that a law must be relatively certain to satisfy the principles of the rule of law is less dubious. ${ }^{8}$ Deep analysis of the rule of law and the principle of certainty in the context of tax is not the focus of this paper; suffice it to say that the main criticism of GAARs is that they flagrantly violate the requirement that laws be certain. The catch-all nature of a GAAR and the countless forms of arrangements to which they must apply means even the most detailed GAAR will be broader than most legal rules. Indeed in a study directed at exactly this issue whether a GAAR breaches the rule of law - the authors concluded that it does. ${ }^{9}$

A breach of certainty here is not simply philosophical rhetoric. It is often argued that because a general anti-avoidance rule is not certain it will have dampening effects on business and the economy, as taxpayers will be unable to plan their affairs in advance. $^{10}$ The argument claims that because of its broad terms, taxpayers cannot know when their arrangement is one which may be subject to the GAAR. Thus, they are forced to choose between engaging in conduct and hoping for a favourable outcome or not undertaking the transaction at all. ${ }^{11}$ This line of argument has

7 Thomas Carothers "The Rule of Law Revival" (1998) 77 Foreign Aff. 95 at [96].

${ }^{8}$ Friedrich A Hayek The Constitution of Liberty (Routledge, London, 1960) at 144; see also Adam Smith "An Inquiry into the Nature and Causes of The Wealth of Nations (Encyclopedia Britannica, first published 1776, 1990) 4056, cited in British Columbia Railway v The Queen (1979) 79 DTC 5020, 5025, as cited in Atkinson at [9], on the important of certainty particularly in the setting of taxation.

${ }^{9}$ Rebecca Prebble and John Prebble "Does the Use of General Anti-Avoidance Rules to Combat Tax Avoidance Breach Principles of the Rule of Law?" 2 VUWLRP 8/2012 21.

10 The importance of certainty in taxation is emphasised often, see Graham Aaronson QC GAAR Study (11 November 2011) at [3] and [5], and OECD Taxpayer's Rights and Obligations: A Survey of the Legal Situation in the OECD Countries (OECD, 1990) at [2.21]; see also Adam Smith above n 8.

${ }^{11}$ Atkinson above $\mathrm{n} 2$ at [55]. 
dissuaded the United Kingdom government from introducing a statutory GAAR in the past, ${ }^{12}$ and is the primary reason for adding detail to a GAAR or ensuring a high threshold for its operation through a misuse/abuse requirement. ${ }^{13}$

In Part VIII this paper explores the proposition that certainty is the wrong goal in the GAAR context. Nonetheless it is important to appreciate the weight placed on the certainty argument in order to understand why some jurisdictions have opted for more detailed GAARs, or GAARs with extra requirements. Enacting enumerated GAARs does not alter the inquiry adopted by the courts under a GAAR analysis and thus enumeration is not as beneficial as it may seem. Moreover, this paper concludes that enumeration can actually undermine the workings of a general anti-avoidance provision.

\section{B Uncertainty Is Necessary in the GAAR Context}

A general anti-avoidance rule must necessarily be a broad rule. The provision is tasked with countering arrangements which satisfy the specific provisions of tax statutes, ${ }^{14}$ yet aim to exploit loopholes in the legislation to obtain tax benefits in an unacceptable manner. They are backstop provisions made necessary by the highly complex content and form of tax law, ${ }^{15}$

12 Judith Freedman "Defining Taxpayer Responsibility: In Support of a General Anti-Avoidance Principle" (2004) 4 BTR 332, at [333].

${ }^{13}$ See Graham Aaronson QC GAAR Study (11 November 2011), at [3] and [5] where the study group's primary concern was certainty and the effect on the economy.

${ }^{14}$ Challenge Corporation Ltd v Commissioner of Inland Revenue [1986] 2 NZLR 513 (CA) at [532] per Woodhouse P; cited with approval by the Supreme Court of New Zealand in Penny $v$ Commissioner of Inland Revenue [2011] NZSC 95, [2012] 1 NZLR 433; [2010] NZCA 231, [2010] 3 NZLR 360 at [47] (litigation known as Penny and Hooper); and see Westpac Banking Corporation v Commissioner of Inland Revenue [2009] NZCA 24 at [184]

15 Judith Freedman above n 12 at [342], see generally David A Weisbach "Formalism in the Tax Law" (1999) 66 The University of Chicago Law Review 860; and see Doreen McBarnet and Christopher Whelan "The Elusive Spirit of the Law: Formalism and the Struggle for Legal Control" (1991) 54 
combined with the ingenuity and creativity of taxpayers who perpetually create new arrangements to use or circumvent technical tax provisions. ${ }^{16}$ Even specific anti-avoidance provisions, enacted to counter specific forms of avoidance directly can be used or circumvented for the purpose of avoidance. ${ }^{17}$ Even when promoting a more targeted and detailed rule, Atkinson noted: ${ }^{18}$
A GAAR will derive its effectiveness against unforeseen and unpredictable forms of tax avoidance by relying on broad terms and principles, and thus to define the outer limits of a GAAR with precision would likely render the provision ineffective.

Tax avoidance is a hard-to-define area of law, ill suited to precise rules, and any attempt to counter avoidance in general will result in inevitable uncertainty. As the majority of the Supreme Court of Canada stated when enlarging the scope of the Canadian GAAR further than previous courts had been willing: ${ }^{19}$

[w]hile parliament's intent is to seek consistency, predictability and fairness in the tax law, in enacting the GAAR, it must be acknowledged that it has created an unavoidable degree of uncertainty for taxpayers.

In relying on broad terms and principles parliaments choose to leave it to the courts to flesh out the provisions and interpret and apply them to facts as they arise. Judges themselves have often criticised the level of judicial discretion needed under a

The Modern Law Review 848, for an explanation of how technical and strict rules can cause loopholes in the law.

${ }^{16}$ Stubart Investments Ltd v The Queen [1984] (SCC) above n 1 at [66].

${ }^{17}$ See for example, Lipson v The Queen (2009) DTC 5528, [2009] SCC 1 at [45]

${ }^{18}$ Atkinson above $\mathrm{n} 2$ at [11].

19 Copthorne Holdings Ltd v Canada 2011 SCC 63, [2011] 3 SCR 721 at [123]. 
GAAR inquiry, for example Kitto $\mathrm{J}$ in Newton when he stated that the then Australian GAAR was overdue for reform by someone who "will take the trouble to analyse his ideas and define his intentions with precision before putting pen to paper." 20 Woodhouse P famously rejected these criticisms of the then New Zealand GAAR, in Challenge Corporation, stating: ${ }^{21}$

It can be said ... that inherent in the approach taken by Parliament is an assurance that some judicial misgivings as to the proper role of the Court concerning the earlier legislation have been misplaced. Most certainly it was open to Parliament to take this approach and I do not accept the view that any of the supposed problems of construing s 99 should persuade the courts that they cannot be resolved by judicial interpretation and so must be left for yet further legislative attention.

This view reflects the general approach of courts in each of the four jurisdictions now, ${ }^{22}$ as judges more readily accept their role under a GAAR inquiry.

\section{Definitions}

Tax avoidance itself is an elusive concept. This is inherent in the fact that it refers to something that is technically legal, yet somehow unacceptable. ${ }^{23}$ A common and helpful starting point for any understanding of tax avoidance is its differentiation from

\footnotetext{
${ }^{20}$ Newton v Federal Commissioner of Taxation (1958) 98 CLR 1, 7 (PC); (1956) 96 CLR 577 (HC) at [597].

${ }^{21}$ Challenge Corporation (CA) above n 14 at [534]

${ }^{22}$ See for example the approach of the Supreme Court of Canada in Copthorne above $\mathrm{n} \mathrm{19}$; the approach of the High Court of Australia in Federal Commissioner of Taxation v Hart [2004] HCA 26; 217 CLR 216; and Federal Commissioner of Taxation v Spotless Services Ltd [1996] HCA 34; (1996) 186 CLR 404.and the approach of the United Kingdom courts in developing and applying the judicial Ramsay principle to counter tax avoidance. 2

${ }^{23}$ Atkinson above n 2 at [3], see also above note 15 and accompanying text.
} 
evasion. $^{24}$ Evasion is illegal. It involves the willful attempt to reduce your tax liability, by fraudulent means. ${ }^{25}$ Tax avoidance is not illegal. Rather, it involves taking advantage of legallyavailable tax-planning opportunities, in order to minimise ones tax liability. ${ }^{26}$

A further line is drawn between acceptable and unacceptable tax avoidance. Defined broadly, avoidance would encompass all legal actions that have the effect of reducing, eliminating or deferring tax liability. ${ }^{27}$ Such a definition would include the simplest of business dealings, for example, merely incurring a deductible expense. Lord Wilberforce outlined the problem when dealing with the New Zealand GAAR in his dissenting judgment in Mangin in 1971, ${ }^{28}$

It fails to specify the relation between the section and other provisions in the income tax legislation under which tax reliefs, or exemptions, may be obtained. Is it legitimate to take advantage of these so as to avoid or reduce tax? What if the only purpose is to use them? Is there a distinction between 'proper' tax avoidance and 'improper' tax avoidance? By what sense is this distinction to be perceived?

The same conundrum presented itself to the House of Lords in Challenge Corporation, where Lord Templeman, speaking for the majority, famously drew the line by reference to a distinction between tax avoidance (to which the GAAR applied) and tax

\footnotetext{
${ }^{24}$ Judith Freedman "The Tax Avoidance Culture: Who Is Responsible? Governmental Influences and Corporate Social responsibility" in Jane Holder and Colm O'Cinneide (eds) Current Legal Problems 2006 (Oxford University Press, 2007) 359 at [362].

${ }^{25}$ Black's Law Dictionary $9^{\text {th }}$ ed at at [1599].

${ }^{26}$ Black's Law Dictionary, $9^{\text {th }}$ ed at [1599].

${ }^{27}$ Atkinson, above n 2 at [4]; see Newton above n 20 per Fullager J at [646] and also Challenge Corporation (PC) above n 14 per Lord Aylmerton at [5,228].

${ }^{28}$ Mangin v Commissioner of Inland Revenue [1971] NZLR 591 (PC) at [602].
} 
mitigation (to which it did not). ${ }^{29}$ Also of note it the decision of the New Zealand Court of Appeal in the first BNZ case, where the majority drew the line between legitimate tax planning and improper tax avoidance. ${ }^{30}$ This terminological distinction has had its critics, ${ }^{31}$ however, with respect, this paper proceeds in agreement with President Cooke when he stated that the distinction is 'both authoritative and convenient for come purposes, 32 and tax avoidance is used in this paper to mean that behavior which is unacceptable and subject to the GAAR, while mitigation refers to acceptable tax planning.

\section{The Role of a $G A A R$}

When defined in this way, so as only to include unacceptable avoidance, avoidance is clearly an evil that should be combatted. $^{33}$ Tax avoidance threatens the integrity of the tax system, reduces government revenue and undermines the equity of any tax regime. ${ }^{34}$ The crucial function of the GAAR is to draw the line between mitigation and avoidance. This paper proposes that because the GAARs in each jurisdiction require judicial interpretation and application, the substantive inquiry is similar in each country. The courts in each jurisdiction adopt a purposive approach and draw on indicative factors to aid their determination. It is this approach of the courts to a GAAR analysis that reveals how abuse/misuse requirements and detailed GAARs do not fundamentally alter the material GAAR inquiry.

${ }^{29}$ Challenge Corporation, above n 14 at [167] - [168]

30 Commissioner of Inland Revenue $v$ BNZ Investments Ltd [2002] 1 NZLR 450 (CA) [BNZ Investments No 1 (CA)] at [39].

31 Lord Hoffman, in MacNiven (HM Inspector of Taxes) $v$ Westmoreland Investments Ltd [2001] UKHL 6, [2003] 1 AC 311at [257], and the majority of the Supreme Court in Ben Nevis Forestry Ventures Ltd $v$ Commissioner of Inland Revenue [2008] NZSC 115, [2009] 2 NZLR 289 ('Ben Nevis') at [95].

${ }^{32}$ Hadlee and Sydney Bridge Nominees Ltd $v$ Commissioner of Inland Revenue (1991) 13 NZTC 8, 116, at [8,122].

${ }^{33}$ Atkinson, above $\mathrm{n} 2$ at [5] and see OECD Secretary-General Report to the G20 Leaders (OECD, St Petersburg, 5-6 September 2013) at [2] and generally, which discusses the need to combat avoidance on an international level.

${ }^{34}$ Atkinson, above $\mathrm{n} 2$ at [5]. 
The following sections compare and assess the way the GAARs from the four jurisdictions distinguish between mitigation and avoidance. In finding that the material inquiry is the same in each case, and that enumeration tends to cause complications, the paper concludes that GAARs achieve their purpose better when drafted in broad terms.

\section{Drawing the Line}

\section{A Introduction}

The primary role of a GAAR, as mentioned, is to distinguish between avoidance and mitigation. This part of the paper briefly identifies the features common to all GAARs which are applied in the beginning stages of any GAAR analysis.

\section{B Basic Characteristics of All GAARS}

Generally, every GAAR requires that a taxpayer:

1. undertakes an arrangement, scheme or transaction, that

2. results in a tax benefit or advantage, where

3. the obtaining of that tax benefit was a purpose of the taxpayer, the level of purpose required varies from not merely incidental to main or dominant.

The first two steps are largely definitional and the terms are drafted as broadly as possible in each of the four jurisdiction's GAARs. Arrangement is defined broadly to ensure taxpayers cannot adopt a certain form of dealing to avoid the scope of the GAAR. Similarly, tax benefit is defined broadly to ensure that any alteration of ones liability to income tax can be subject to the GAAR provision. Broad definitions rather than drawing a line between mitigation and avoidance are aimed at providing allinclusive first steps to a GAAR inquiry.

All four GAARs also require a mental element of the arrangement; that the taxpayer had a purpose of obtaining the tax benefit. Here the GAAR analysis begins to draw the line as any 
arrangement found to have only bona fide commercial purposes other than to obtain a tax advantage will not be caught by a GAAR. The New Zealand GAAR requires only that the tax avoidance purpose be not merely incidental to another purpose, while Australia, Canada and the United Kingdom each require a stronger mental element. ${ }^{35}$

Because Australia does not have a misuse/abuse requirement the courts have considered that the key to whether Part IVA applies lies in the purpose test. ${ }^{36}$ That approach combined with the detail of Part IVA has had some negative consequences in Australian jurisprudence which are discussed in Part XXX below.

New Zealand, which also lacks a misuse/abuse requirement, has a judicially developed test to guide a GAAR inquiry known as the parliamentary contemplation test. Rather than emphasising the purpose of the arrangement the parliamentary contemplation test asks 'whether the impugned arrangement, viewed in a commercially and economically realistic way, makes use of the specific provision in a manner that is consistent with Parliament's purpose.' ${ }^{37}$ The courts in Canada, although dealing with a misuse/abuse requiring GAAR have, in substance, adopted a similar approach to New Zealand. The following part of this paper discusses these two approaches, and establishes that the material inquiry is not altered by a misuse requirement.

\footnotetext{
${ }^{35}$ Australia s 177D 'dominant purpose' Income Tax Assessment Act 1936 (Cth) (Austl.); Canada s 245(3) 'unless undertaken primarily for bona fide purposes' Income Tax Act 1985 (Can), United Kingdom 'main purpose' s 207 Finance Act 2013 (UK).

${ }^{36}$ Hart above n 22 at [92]; see also explanation in: Christine Barron, General Manager of Corporate and International Tax Division, Australian Treasury, "Anti-Avoidance Rules in Taxation: Striking a Balance" (speech to the Asian Tax Authorities Symposium, Kuala Lumpur, 4 September 2012) and Tax Laws Amendment (Countering Tax Avoidance And Multinational Profit Sharing) Bill 2013 Explanatory Memorandum (Australia).

${ }^{37}$ Ben Nevis above n 31 at [109].
} 


\section{Abuse and Misuse Requirements}

Because the Canadian GAAR (s 245) has been subject to judicial interpretation and application, it exemplifies how an abuse misuse/requirement works in practice. Upon examination and comparison with New Zealand's broad rule, it seems that the Canadian GAAR works similarly to New Zealand's.

\section{Canada-The Comparison}

What is important to note here is that the comparison does not attempt to claim that the application of each GAAR is exactly the same, or that any case would be decided in exactly the same way. Rather, that the inquiry is not fundamentally altered as a direct consequence of the extra abuse and misuse requirement. In other words, given that the substantive inquiry and approach of the courts in their attempt to draw the line between avoidance and mitigation is similar in each case, it seems that the abuse requirement does not fundamentally alter where that line is to be drawn. Hence, the principle purpose of enacting a misuse requirement, to ensure certainty, is similarly achieved by each GAAR. The relevant text of the Canadian provision provides: ${ }^{38}$

(4) The GAAR applies to a transaction only if it may reasonably be considered that the transaction,

(a) would, if this Act were read without reference to this section, result directly or indirectly in a misuse of the provisions of any one or more of

(i) this Act, the Income Tax regulations,

(ii) the Income Tax Application Rules,

(iii) a tax treaty, or

(iv) any other enactment that is relevant in computing tax or any other amount payable by or refundable to a person under this Act or in determining any amount that is relevant for the purposes of that computation; or

\footnotetext{
${ }^{38}$ Income Tax Act 1985 (Can) s 245(4).
} 
(b) would result directly or indirectly in an abuse having regard to those provisions, other than this section, read as a whole.

The English wording is disjunctive, using misuse (in (a)) and abuse (in (b)), while the French wording is non-disjunctive using the one word l'abuse. ${ }^{39}$ The courts have overcome this apparent anomaly, preferring to engage in a single enquiry into whether the provisions have been misused or the Act abused having regard to the Act as a whole. ${ }^{40}$ Much ink has been dedicated to this discrepancy over the years, however, for the purposes of this paper it is not of great consequence and thus it need not be delved into any further.

This paper proposes that despite the disparity in wording, Canada's provision and New Zealand's provision, in practice, catch the same behavior. Upon examination of judicial interpretation and application of the two provisions one can easily see how they operate to affect the same kinds of behavior. What one can observe from this comparison is that an abuse requirement does not significantly alter the inquiry under a GAAR and does not change where the line will be drawn. In this way, the level of certainty under each GAAR must be the same.

\section{The Approach}

The approach of the courts to section 245(4) was clarified and set out by the Supreme Court in Copthorne Holdings. ${ }^{41}$ The court held that the abuse or misuse inquiry requires a single two-stage test as follows:

1. One must determine the object spirit or purpose of the provisions ... that are relied on for the tax benefit, having regard to the scheme of the Act, the relevant provisions

\footnotetext{
${ }^{39}$ Canada Trustco Mortgage Co v Canada (2005) SCC 54 at [38]

${ }^{40}$ Canada Trustco at [39]

${ }^{41}$ Copthorne Holdings Ltd v Canada 2011 SCC 63, [2011] 3 SCR 721.
} 
and permissible extrinsic aids, ${ }^{, 42}$ this requires determining the rationale that underlies the words of the provision. ${ }^{43}$

2. Then consider whether the transaction respects or frustrates this purpose. ${ }^{44}$

If the transaction, so considered, either achieves an outcome that the provision was intended to prevent, or defeats the underlying rationale for the provision, or circumvents the provision in a manner that frustrates its object, spirit or purpose, it will constitute avoidance. ${ }^{45}$ The current New Zealand approach is, in substance, the same. As the Commissioner has outlined in his interpretation statement of 2013, the New Zealand approach is to: ${ }^{46}$

1. Identify Parliament's purpose for the particular provisions and then ask;

2. Does the arrangement (viewed in a commercially and economically realistic way) use or circumvent the relevant provisions in a manner that is inconsistent with the identified purpose.

Looking past the fact that the actual articulations of the tests differ, the essential inquiry is the same in sequence and substance. Both jurisdictions begin the examination by ascertaining the purpose of the relevant specific provisions. Subsequently, the courts must examine the facts and characteristics of the arrangement and decide whether the impugned arrangement is in line with the identified purpose, or instead goes against it.

${ }^{42}$ Copthorne above $\mathrm{n} 41$ at [69].

${ }^{43}$ Copthorne above $\mathrm{n} 41$ at [69].

${ }^{44}$ Copthorne above $\mathrm{n} 41$ at [71].

${ }^{45}$ Copthorne above $\mathrm{n} 41$ at [72]

${ }^{46}$ Interpretation Statement: Tax Avoidance and the Interpretation of Sections BG 1 and GA 1 of the Income Tax Act 2007 (Public Rulings Unit, Office of the Chief Tax Counsel, 13 June 2013) at p 4 [17] and generally; Ben Nevis above n 31 at [102], [103], [107], [108] [109] 
Examples of judicial analysis from each jurisdiction are illustrative of the likeness. In Global Equity Fund Ltd Mainville JA found that the transactions were abusive of the relevant specific provisions. ${ }^{47}$ His Honour found that the fundamental rationale underlying the provisions is that, in order to be used for taxation purposes, business losses must be grounded in some form of economic or business reality. In light of that determination, the court held that the purpose of the provisions would be defeated if paper losses could be used to avoid the "payment of taxes otherwise owed on the profits resulting from the real world business operations of Global." 48

The approach in the New Zealand case Alesco is remarkably similar to the approach in Global Equity. In the High Court Heath $\mathrm{J}$ analysed Parliament's purpose and identified that the financial arrangements rules are intended to match real income and real expenditure. ${ }^{49}$ This observation, he stated, reflects the object of the specific provisions, namely, to "prevent deferring income and advancing expenditure." 50 The Court of Appeal also concluded that the word expenditure in the specific provisions required an actual outflow of money or an obligation to make a payment. ${ }^{51}$ The court held that the features of the financial arrangements rules suggested Parliament would not have intended for the rules to be used to claim interest deductions for which the taxpayer was not liable or did not pay. ${ }^{52}$ Here, the court followed the same approach as in Equity, by identifying the purpose of the specific provisions and testing the impugned transaction against that purpose in light of the economic reality.

${ }^{47}$ The Queen v Global Equity Fund 2013 DTC 5007 [5226], 2012 FCA 272 at [62] specific provisions in question were: Sections 3, 4, 9, and 11 of the Income Tax Act (Can).

${ }^{48}$ Global Equity Fund 2013 DTC 5007 [5226], 2012 FCA 272 at [66]-[68].

${ }^{49}$ Alesco New Zealand Limited and Ors v Commissioner of Inland Revenue [2013] NZCA 40 (HC No 2) at [105] (emphasis in original).

${ }^{50}$ Alesco (HC) above $\mathrm{n} 49$ at [105], referring to s EH 20 of the Income Tax Act

${ }^{51}$ Alesco (CA) above $\mathrm{n} 49$ at [70].

${ }^{52}$ Alesco (CA) above n 49 at [71] and [72] 
In each case the court found in favour of the Commissioner as specific provisions had been used outside their intended scope.

Interestingly, this approach to a GAAR provision seems to be taken even further in the country with an abuse and misuse requirement. In Inter-Leasing Inc (a Canadian case), ${ }^{53}$ Aston J identified the purpose of the provisions broadly, significantly opening up the possibility for their abuse. ${ }^{54}$ His Honour held that the purpose of the specific provisions was to raise revenue. Thus, because the transactions sought to avoid the charging provision, they were contrary to its objective and therefore abusive. His Honour went on to hold: ${ }^{55}$

"A charging provision is not aimed at encouraging or discouraging certain taxpayer decisions or behavior. The purpose, plain and simple, is to raise revenue. As a charging provision, the purpose of $\mathrm{s}$ 2(2) of the OCTA ... is to define the tax base as broadly as possible in order to generate tax.

As a consequence, it will be very difficult to find that any 'tax benefit' resulting from an 'avoidance transaction' is consistent with the 'object spirit and purpose' of this category of legislative provision. It seems unlikely there will be any underlying policy choice by the legislator that will afford refuge for the taxpayer under the third [i.e. abuse] part of the analytical framework."

Here Aston $\mathrm{J}$ has drawn the line for arrangements that will constitute avoidance, and despite the presence of a misuse/abuse requirement, has provided a very low threshold for the operation of s 245 .

\footnotetext{
${ }^{53}$ Inter-Leasing Inc v Ontario (Revenue) 2013 ONSC 2927, at [41]-[43]

${ }^{54}$ Inter-Leasing Inc, at [41]-[43]

${ }^{55}$ Inter-Leasing Inc, at [42]-[43].
} 


\section{$V$ Central Objection to the Approach in Canada and New Zealand:}

\section{A The Objection}

The objection most often levied against the approach taken by the Canadian and New Zealand courts to GAAR analysis is that it is little more than a rule of construction and takes us no further than a purposive interpretation.

Purposive interpretation is an accepted and common approach to statutory construction. ${ }^{56}$ It involves "interpreting specific provisions in accordance with the object or purpose of the provisions as construed from the words used in their wider context." ${ }^{, 57}$ If an arrangement is designed and carried out in a manner inconsistent with the object and purpose of the particular provisions, then shouldn't a purposive interpretation be enough to deny that arrangement? A central feature of the GAAR is that the impugned arrangements satisfy the technical requirements of the specific provisions in question, ${ }^{58}$ once this has been established a GAAR analysis may be begun. Therefore, there seems to be an anomaly if an arrangement satisfied a specific provision purposively construed, yet was then found to frustrate the purpose of the arrangements under a GAAR analysis. In other words, under the two-step tests outlined above, the GAAR really takes us no further than a purposive approach to statutory construction. However, the next section explains that a gear

\footnotetext{
${ }^{56}$ See Interpretation Act 1999 (NZ) s 5; Barclays Mercantile Business Finance Ltd v HM Inspector of Taxes, [2004] UKHL 51; [2005] STC 1, at [32]; IRC v McGuckian [1997] 1 WLR 991, per Lord Steyn at 1000, and Lord Cooke at 1005, explaining the Ramsay principle; Copthorne above n 41 at [70] Citing Canada Trustco above n 39 at [47]; Austin v The Commonwealth (2003) 51 ATR 654, at [723????]; and Acts Interpretation Act 1901 (Cth) s 15AA

${ }^{57}$ Atkinson above $\mathrm{n} 2$ at 42; see also Interpretation Act 1999 s 5 (NZ).

${ }^{58}$ Challenge Corporation Ltd $v$ Commissioner of Inland Revenue [1986] 2 NZLR 513 (CA) at [532] per Woodhouse P; cited with approval by the Supreme Court of New Zealand in Penny v Commissioner of Inland Revenue [2011] NZSC 95, [2012] 1 NZLR 433; [2010] NZCA 231, [2010] 3 NZLR 360 at [47] (litigation known as Penny and Hooper).
} 
provision provides for a broad inquiry and allows courts to go further than they would under a simple purposive construction.

\section{B The limits of the purposive approach to statutory interpretation}

While the purposive approach is an accepted modern approach to interpretation and is regularly used by judges in many areas of the law, it still has, and always will have, its limits.

The purposive approach is inherently limited, and judges, warning against judicial law making, frequently stress those limits. Indeed, when concluding in favour of the taxpayer in the United Kingdom case Jones, Carnwath LJ expressed that "The lack of a clearly ascertainable legislative purpose underlines the need for caution." ${ }^{59}$ Courts are still limited to the words of the statute, as Lord Hoffman has emphasised, the intention of Parliament can be expressed only through statute, and it is the words of that statute, as interpreted by the courts, that embodies the intention. ${ }^{60}$ Tokeley outlines two limits to the purposive approach. ${ }^{61}$ First, it should only be applied where the words of the statute are uncertain, ${ }^{62}$ where a literal approach will not suffice. Secondly, it can only be used to employ a meaning that the words of the statute are reasonably capable of bearing. ${ }^{63}$

While these limits are easily referred to, they are complex in practice. When can it be said that a word's meaning is uncertain? At what point does a meaning become one that the word cannot

${ }^{59}$ Jones v Garnett [2007] UKHL 35; [2005] EWCA 1553; [2005] EWHC 849 (Ch) (CA) at [108].

${ }^{60}$ Lord Hoffman, "Tax Avoidance” (2005) British Tax Review 197, 204

CHECK; see also Lord Hoffman in Auckland Harbour Board (2001) 20 NZTC 17, 008, at [2], [4], [5], [6], [8], [9], and [11].

61 Kate Tokeley "Interpretation of Legislation: Trends in Statutory Interpretation and the Judicial Process" (2002) 33 VUWLR 965 at [969].

${ }^{62}$ Kate Tokeley, at [969].

${ }^{63}$ Ibid. 
reasonably bear? ${ }^{64}$ Significantly, when these difficulties come to bare, courts may and often do err on the side of caution. As Iacobucci $\mathrm{J}$ stated of the approach in Canada, in qualifying his own endorsement of the modern purposive approach:

"[T]his Court has also often been cautious in utilizing tools of statutory interpretation ... it would introduce intolerable uncertainty into the Income Tax Act if clear language in a detailed provision of the Act were to be qualified by unexpressed exceptions derived from a court's view of the object and purpose of the provision." 65

Moreover, a purposive approach alone will often fail to produce a unified approach. Goldberg QC noted that in the United Kingdom under the judicial Ramsay Principle and a purposive approach, most of the cases that broadened the Court's role in stopping tax avoidance were followed by another case, which narrowed the role. ${ }^{66}$

Nonetheless, it has been argued that in order to go further than purposive interpretation a GAAR needs both an abuse requirement and a legislated list of criteria that indicate abusive avoidance. ${ }^{67}$ For many decades the United Kingdom courts have continued to develop and apply a judicial shield against tax avoidance, known as the Ramsay principle, ${ }^{68}$ which asks whether

\footnotetext{
${ }^{64}$ See Tokeley, above $\mathrm{n} 61$.

${ }^{65} 65302$ British Columbia Ltd v The Queen [2000] 1 CTC 57, SCC at [79][80]

${ }^{66}$ David Goldberg "The Approach of the Acourts to Tax Planning Schemes" Taxbar $<$ http://www.taxbar.com/documents/Approach_Courts_David_Goldberg.pdf $>$

${ }^{67}$ Atkinson above $\mathrm{n} \mathrm{2}$, a paper written in the stages leading up to the introduction of the United Kingdom's GAAR at [56].

${ }^{68}$ First propounded in $W T$ Ramsay Ltd v Inland Revenue Commissioners [1982] AC 300.
} 
'the relevant statutory provisions, construed purposively, were intended to apply to the transaction, viewed realistically. ${ }^{, 69}$

Given the strength of this judicial principle, the United Kingdom government may have been concerned to ensure their GAAR went further than a purposive approach, which may also explain the adoption there of a detailed gear. This paper proposes that the GAAR analyses in both New Zealand and Canada do in fact go beyond purposive construction, and thus legislated details are neither necessary nor desirable.

\section{The Ramsay Principle versus a GAAR analysis}

Comparisons in this area are difficult. In order to demonstrate that the New Zealand GAAR, for example, has a broader reach than the purposive approach of the United Kingdom courts, one would ideally compare a case from each jurisdiction, with exactly the same facts, in a setting of exactly the same income tax laws, but for the presence of a GAAR. This, unfortunately, is impossible. We are forced to hypothesise.

Income splitting or shifting provides a good setting for a comparison because the facts are more easily understood than other avoidance cases, which often involve highly complex financial concepts and arrangements. Briefly, income shifting is where income is allocated or shifted to a taxpayer with a lower tax rate, or with losses to use, and deductions or credits are allocated to those in higher tax brackets. ${ }^{70}$

Jones $v$ Garnett (Inspector of Taxes) ${ }^{71}$ is an income splitting case from the United Kingdom. The taxpayer ( $\mathrm{Mr}$ Jones) established a company with his wife for his computer consultancy business, each spouse bought one share for $£ 1$ each. Mr Jones generated all the income for the company, and his wife provided some administrative services for which she was paid a fair

${ }^{69}$ Collector of Stamp Revenue v Arrowtown Assets Ltd [2003] HKCFA 46 at [35]

70 http://www.ird.govt.nz/taxagents/compliance/news/archive/compliancenews-atp.html

71 Jones $v$ Garnett above n 59. 
salary. ${ }^{72} \mathrm{Mr}$ Jones however, received a salary 'plainly less' than he could have earned in the market. ${ }^{73}$ This set-up allowed the company to earn profits and distribute them as dividends to each shareholder. The dividend payable to Mrs Jones was taxable at a lower rate than it would have been if it had been added to the income of Mr Jones, ${ }^{74}$ or if he had received a realistic salary. The structure resulted in a lower overall tax liability for the couple. The House of Lords, however, found in favour of the taxpayer.

The New Zealand case of Penny $v C I R^{75}$ (also known as Penny and Hooper) provides a good comparator. The case involved two orthopaedic surgeons who each incorporated their practices, those companies being owned by family trusts. The taxpayers became employees of those companies and, as in Jones, their work represented all the earning power of the companies. Although continuing business much as they had before, after establishing their companies, the taxpayers earned substantially lower salaries. The balance of the income not paid out as salary was taxed at the company rate of $33 \%$, rather than the $39 \%$ tax rate the salaries would have been subject to. Importantly, in each case the taxpayers continued to enjoy the use and control of the earnings much as they would have, if the profit been paid directly as salaries. The Supreme Court of New Zealand found in favour of the Commissioner and held that the arrangements were tax avoidance and void against the Commissioner for tax purposes.

This paper proposes that had Jones been tried in New Zealand, the scheme would have been found to be tax avoidance. The characteristic of the arrangement that so offended the Commissioner in Penny and Hooper, was the fixing of the salaries at such an artificially low level. That element also lead to the court's finding of a tax avoidance purpose and ultimately to its finding of tax avoidance. In both cases public interest spiked

\footnotetext{
${ }^{72}$ Jones $v$ Garnett at [4]

${ }^{73}$ Jones $v$ Garnett at [4].

${ }^{74}$ Jones $v$ Garnett at [5].

${ }^{75}$ Penny above n 58.
} 
because of the so-called ordinary nature of the structures, ${ }^{76}$ a factor that was not overlooked by the Supreme Court: ${ }^{77}$

The structure both taxpayers adopted when they transferred their businesses to companies owned by their family trusts was, as a structure, entirely lawful and unremarkable.

However, the artificial fixing of the salaries was enough to indicate the purpose of the arrangement and to conclude it was tax avoidance. ${ }^{78}$ An artificially low salary was also present in Jones. Furthermore, the court found that Mr Jones's decision to set up his company as he did was 'tax driven and not commercially driven, ${ }^{79}$ an important factor under the New Zealand BG 1 inquiry. ${ }^{80}$

Admittedly, there were certain provisions in play in the Jones case, such as a specific anti-avoidance rule and a relevant exception to it. ${ }^{81}$ In fact, the Ramsay principle was only briefly mentioned in the House of Lords judgment and was not referred to in the lower courts. Why was the principle not argued by the Inspector? Perhaps the presence of a specific anti-avoidance rule was seen as excluding the operation of the principle? Whatever the reason, had the case been a New Zealand one, the GAAR would not have been overlooked as Ramsay was. It would have

\footnotetext{
76 James Bailey, August 2007 http://www.taxinsider.co.uk/231Arctic_Systems_the_Good_News_and_the_Bad_News.html; see also http://www.cfwaccountants.co.uk/accountancy_info.php?article=316\&name $=\mathbf{J}$ ones; and http://my.lawsociety.org.nz/in-practice/the-changing-law/casecommentary/keep-a-steady-focus-on-what-bg-1-says-penny-and-hooper-v-cir; and; http://www.deloitte.com/view/en_nz/nz/63b268c391222310VgnVCM3000001 c56f00aRCRD.htm

${ }^{77}$ Penny and Hooper above n 58 at [33]

${ }^{78}$ Penny and Hooper above $\mathrm{n} 58$ at [34]-[36] and [47]-[48]

${ }^{79}$ Jones above $n 59$ at [10].

${ }^{80}$ s BG 1 and YA 1 Income Tax Act 2007 (NZ).

${ }^{81}$ Chapter IA of Part XV of the Income and Corporation Taxes Act 1988 (UK), specifically ss 660A and 660G.
} 
been invoked to counter the arrangement, and it would have succeeded as it did in Penny.

This conclusion is based on a number of considerations. Firstly, the elements of the arrangement that were emphasised by the Supreme Court in Penny as leading to their decision were also present in Jones (the presence of artificiality, seen in the artificially low salary, and the fact that Mr Jones still enjoyed the benefit of the profit). Secondly, it is well established in New Zealand that the presence of a specific anti-avoidance provision does not prevent the application of the GAAR, ${ }^{82}$ thus the presence of the specific anti-avoidance rule in the United Kingdom would not have prohibited the operation of the GAAR. Finally, as mentioned, the courts found a purpose of tax avoidance in Jones, an element essential and telling under a GAAR inquiry.

Now that it has been established that the Canadian and New Zealand GAAR inquiries are in substance the same, and that they both go further than a purposive approach and the Ramsay principle of the United Kingdom, the paper turns to consider United Kingdom's s 207.

\section{The United Kingdom - An Enlightened GAAR?}

The benefit of comparing and examining the United Kingdom GAAR is that it was adopted much later than the other three GAARs. As such, the United Kingdom had the advantage of learning from international experience, ${ }^{83}$ and was able to choose

${ }^{82}$ Challenge above $\mathrm{n} 58$ at [559]; and Penny above n 58 at [48]. See also Interpretation Statement of the Commisisoner 2013 above n 46 at p 17 [67][71].

${ }^{83}$ Judges on the advisory panel were specifically chosen for their experience with GAARs from different jurisdictions, Graham Aaronson QC GAAR Study (11 November 2011) at [11]. 
what seemed to be the most effective aspects of various GAARs. ${ }^{84}$ Examining the end result in the form of s 207, and the report that led to it, ${ }^{85}$ highlights where the United Kingdom government's concerns lie and how its chosen GAAR might address those concerns. It is important to understand the concerns the United Kingdom government had when contemplating the introduction of their GAAR, as these concerns shed light on the advantages the United Kingdom Parliament attribute to the abuse requirement and therefore the matters we must measure a broader GAAR by to see if it comes short.

Analysing s 207 in light of the approaches in other jurisdictions it is hard to conclude that the enumerated United Kingdom rule really transforms the GAAR inquiry.

\section{A The Aaronson Report}

The Aaronson report is the product of a Treasury commissioned inquiry, ${ }^{86}$ led by Aaronson QC, and it is that report which provided the basis of what was eventually enacted, in the form of section 207. The issue to be considered was complex, requiring an overall analysis to decide whether introducing a GAAR would be a positive step for the United Kingdom. The inquiry was not simply asking whether a GAAR could be used to counter avoidance, but whether, considering all factors, any positives outweighed the negatives.

The 'most critical' factor was whether a GAAR would make the United Kingdom a less attractive place for business and investment, ${ }^{87}$ other factors included ensuring sufficient certainty, and avoiding undue compliance costs for businesses and individuals. Ultimately, these factors led to the rejection of a broad-spectrum general anti-avoidance rule. The report stated a

\footnotetext{
84 Judith Freedman "GAAR: challenging assumptions" (27 September 2010)

Tax Journal < http://www.taxjournal.com/tj/articles/gaar-challengingassumptions>

${ }^{85}$ s 207 Finance Act 2013 (UK); and Aaronson Report above n 13.

${ }^{86}$ Aaronson Report above $\mathrm{n} 13$.

${ }^{87}$ Aaronson Report above n 13.
} 
broad GAAR would carry a 'real risk of undermining the ability of business and individuals to carry out sensible and responsible tax planning'. ${ }^{88}$ Interestingly, the phrase responsible tax planning was used multiple times throughout the report, with continuing claims that a more moderate rule targeted at abusive avoidance would have the benefit of not applying to the centre ground of responsible tax planning. ${ }^{89}$ This paper proposes that such a distinction is, with respect, ill founded. It is clear that no GAAR, broad or otherwise, is aimed at affecting the centre ground of responsible tax planning. There are several possible reasons for the Report's use of this phraseology.

Possibly, the phrase reveals that the targeted GAAR is intended to affect all unacceptable avoidance, as long as it does not fit into the centre ground of responsible planning, in which case it is targeted, from its very inception, at the same behavior as a broad-spectrum GAAR such as New Zealand's or Australia's, which target unacceptable avoidance without using an 'abuse' threshold. Here, each GAAR is intended to draw the line in the same place.

Another possibility is that the report has chosen to refrain from admitting that a substantial number of undesirable avoidance arrangements will fall outside of the scope of the antiabuse rule. Here, the bulk of arrangements that may lie between abusive and responsible are left unaffected. Under this scenario, perhaps we see why the guidelines made explicit the intention to keep the judicial Ramsay principle alive and well - to ensure any behavior that is unacceptable, yet short of abusive, still can and will be countered. ${ }^{90}$

\footnotetext{
${ }^{88}$ Aaronson Report, above $\mathrm{n} 13$ at [3].

${ }^{89}$ Aaronson Report, above n 13 - more than fifteen times at [4], [5], [6], [7], [9], [28], [30], [32], [34] and [40].

90 W T Ramsay Ltd v Inland Revenue Commissioners [1982] AC 300 (HL) and HM Revenue and Customs (HMRC's GAAR Guidance) (15 April 2013) (United Kingdom) at [B8.3].
} 
The use of such phraseology could also imply the study group and ultimately the government feels that a broad-spectrum GAAR, which lacks an abuse requirement, does in fact affect the centre of responsible tax planning. In other words, after careful assessment of international experience and considering potential practical examples within the United Kingdom context, the study group decided that a broad-spectrum GAAR would catch and affect responsible tax planning. This view is shared by many, often from the finance and business worlds, who refer to the planning behavior as responsible business.

With respect, this paper disagrees. General anti-avoidance rules, broad or otherwise, have the common chief aim of leaving untouched ordinary business and family tax planning. Hence, the New Zealand Commissioner's continued acceptance that a literal application of the GAAR is undesirable, as it would affect much more than is desirable. ${ }^{91}$

Reactions to certain cases won by the Commissioner over the years reveal that the view that GAARs encroach on acceptable planning is alive and well. For example, several people from the tax planning industry viewed the recent decision in Alesco as a step too far. ${ }^{92}$ However, the same reactions followed many other avoidance cases when their judgments were laid down in favour of the Commissioner, such as Penny and Hooper. While some may always hold the view that a line is being crossed and the commercial world is suffering unjustifiably, it seems the Revenue Department and the government do not agree. The government has had every opportunity to amend or qualify the broad spectrum BG 1 provision. However, it has chosen not to. Nor

\footnotetext{
${ }^{91}$ Interpretation Statement of the Commissioner above $\mathrm{n} 46$ at [11]-[12], see also Challenge above $\mathrm{n} 58$ at [532] and [541]; Commissioner of Inland Revenue v BNZ Investments Ltd [2002] 1 NZLR 450 (CA) [BNZ Investments No 1 (CA)] at [41].

${ }^{92}$ Alesco above $\mathrm{n} 49$.
} 
have the Australian or Canadian governments. Indeed, Australia's government has amended Part IVA to broaden its scope.

\section{B The Double Reasonableness Test}

The Guidelines issued by the HMRC describe the double reasonableness test as the crux of the GAAR test, and the feature that provides ultimate taxpayer protection. ${ }^{93}$ The test is the most unique aspect of s 207, and as such it is analysed to see what changes it could make to a gear inquiry.

The test does not ask whether entering into or carrying out the arrangements was a reasonable course of action in relation to the relevant tax provisions. In stead, it asks whether there can be a reasonably held view that entering into or carrying out the tax arrangements in question was a reasonable course of action. ${ }^{94}$

The test is meant to recognise that there are some arrangements which some people would regard as reasonable, while others would not. ${ }^{95}$ Given that recognition, the judge is required to consider the range of reasonable views that could be held in relation to the arrangements. ${ }^{96}$ In this way, the double reasonableness test seems to lift the threshold for what will be found to be abusive avoidance. However, the double reasonableness inquiry is qualified in the legislation, which states:

(2) "Tax arrangements are "abusive" if they are arrangements the entering into or carrying out of which cannot reasonably be regarded as a reasonable course of action in relation to the relevant tax provisions, having regard to all the circumstances including -

\footnotetext{
${ }^{93}$ HMRC Guidelines above $\mathrm{n} 90$, at $\mathrm{p} 24$ [C5.10.1\}

${ }^{94}$ HMRC Guidelines above $\mathrm{n} 90$ at $\mathrm{p} 24$ [C5.10.1]

${ }^{95}$ HMRC Guidelines above $n 90$ at $p 10$ [B12.2]

${ }^{96}$ HMRC Guidelines above n 90, emphasis added.
} 
(a) whether the substantive results of the arrangements are consistent with any principles on which those provisions are based (whether express or implied) and the policy objectives of those provisions,

(b) whether the means of achieving those results involves one or more contrived or abnormal steps,

(c) whether the arrangements are intended to exploit any shortcomings in those provisions. ${ }^{97}$

The guidelines further emphasise this qualification by stating "It is necessary to test any given view to see whether that view itself can be regarded as reasonable, having regard to the purposes of the GAAR legislation and the factors that it requires to be taken into consideration." 98 The guidelines claim that this qualification recognises that some people hold extreme views. The United Kingdom GAAR is based on the premise that taxation is the principal means by which the necessary functions of the state are funded, and its basic purpose is to deter or counteract deliberate exploitation of the legislation. ${ }^{99}$ Therefore, someone's view, if based on some other proposition, such as a belief that people are free to exploit any shortcomings in tax legislation, will be unreasonable for the purposes of the GAAR.

So, while the double reasonableness test appears, at first instance, to raise the threshold for abusive avoidance, upon closer analysis, it test against the approach of the courts in New Zealand. Harrison $\mathrm{J}$ in Westpac, after identifying the purpose of the foreign tax regime, took the view that Parliament would have expected foreign tax to actually have been paid. At [612]

"As demonstrated by s LC 1(3A), the FTC regime was intended to provide New Zealand taxpayers with credits for tax paid in a foreign jurisdiction ... I accept, as Wild $\mathrm{J}$ did, the Commissioner's argument that the

\footnotetext{
${ }^{97}$ Finance Act 2013 (UK) s 207(2), (emphasis added).

${ }^{98}$ HMRC Guidelines, above $\mathrm{n} 90$ (emphasis added).

${ }^{99}$ HMRC Guidelines above n 90 at p 25 [C5.10.5] - [C5.10.6].
} 
actual payment of foreign tax is the policy foundation of the FTC regime and that, without such a payment, there is nothing against which to allow a credit."

As we have seen, this is the same approach of the Canadian courts - to identify the purpose of the particular provision and then see if the arrangement contravenes that purpose. Is it possible that, under the double reasonableness test, a different outcome would result? It seems that in a world of possibilities it could reasonably be regarded as a reasonable course of action to gain a foreign tax credit when no foreign tax had been paid. Tax legislation is extremely complex, and the commercial environment is increasingly competitive in the global economy. Given the widely held view that there is no dichotomy between tax avoidance and commercial decision making, there could be a reasonably held view that the Westpac scheme was a reasonable course of action for a commercially competitive enterprise.

However, if a reasonably held view for the purposes of the GAAR must be premised on the underlying rationale of the GAAR, the range of reasonably held views is fundamentally limited. To adopt Harrison J's approach above, in light of the words of the United Kingdom test: if regard must be had to the substantive results of the arrangements (the obtaining of a foreign tax credit), and to whether those results are consistent with the principles upon which the provisions are based and the policy objectives of the provisions (to provide a tax credit for tax paid in a foreign jurisdiction), then a view that obtaining a foreign tax credit where no foreign tax had been paid it seems cannot be a reasonably held view in relation to the GAAR. Rather, it is based on the idea that it is acceptable to exploit shortcomings in the legislation, and thus is abusive tax avoidance under the double reasonableness test.

\section{The Broadened Inquiry - Factors Courts Consider}

Parts IV and $\mathrm{V}$ above outlined the general approach of the Canadian and New Zealand courts, and the idea that under the 
gear a court's analysis goes further than a mere purposive approach. This part of the paper explores the idea that a gear inquiry is broader than ordinary statutory construction. It is this concept - a broadened inquiry - and the substance of that inquiry that reveals the similarities of the workings of each GAAR, because under a broad inquiry the courts in each country look to indicative factors to aid their determination.

\section{A How the Inquiry Is Broadened}

\section{A purpose of tax avoidance becomes justifiably relevant}

Most obviously, the general anti-avoidance rules in each jurisdiction make the having of a tax avoidance purpose, or the purpose of gaining a tax benefit, relevant. ${ }^{100}$ Indeed, in Australia it is well established that the fulcrum upon which Part IVA turns is whether a person or persons who participated in the scheme did so for the sole or dominant purpose of gaining the identified tax benefit. $^{101}$

A taxpayer's subjective intention is not relevant to a finding of tax avoidance, rather it is the objective purpose of the arrangement as identified through a wide analysis of all aspects of the arrangement. ${ }^{102}$ In this way, the inquiry into purpose invites a consideration of indicative factors, which in turn contribute to a conclusion on whether the arrangement is a tax avoidance arrangement. Part IVA of Australia lists eight objective indicia to be considered when answering the question of purpose. $^{103}$

${ }^{100}$ s 245(3) Income Tax Act (Can.); s 177D Income Tax Assessment Act (Austl.); s BG1 (1) Income Tax Act (NZ); and s 207(1) Finance Act 2013 (UK).

${ }^{101}$ Callinan J in Hart above n 22 at [92]; endorsed by Tax Laws Amendment (Countering Tax Avoidance And Multinational Profit Sharing) Bill 2013 Explanatory Memorandum (Australia).at [1.71] and [1.125].

${ }^{102}$ See; Ontario Ltd $v$ The Queen 2012 FCA 259; HMRC Guidelines above n 90 at p 16 [C3.3]; Hart above $\mathrm{n} 22$ at [37] and [86]; and Glenharrow Holdings Ltd v Commissioner of Inland Revenue [2008] NZSC 116, [2006] 2 NZLR 359 at [38] and Ben Nevis above $n 31$ at [102].

${ }^{103}$ Income Tax Assessment Act s 177D (Austl.) 
This leads to the second aspect of the broadened inquiry, the substantive analysis and the factors considered.

\section{Indicative Factors Considered Under a GAAR Analysis}

This part examines the way each jurisdiction deals with denotative factors. It is found that the inquiry under each GAAR is essentially the same in substance, despite different legislative wording. How each court employs and applies indicative factors under a GAAR analysis epitomises the similarities in approach and reveals that the material inquiry is the same.

The approach of the United Kingdom is not considered in this part because the courts had not yet dealt with s 207 when this paper was written.

\section{B How Does the GAAR Allow For Factors to Be Considered?}

As discussed above, there are important limitations to the purposive approach. Importantly, an analysis under a general anti-avoidance provision takes the inquiry further than purposive construction, by allowing the courts to consider a wide range of factors that may not ordinarily be considered through purposive interpretation.

Justice Rothstein explained the difference in Canada between purposive construction and a GAAR analysis in Copthorne. His Honour noted first that the purposive approach is the same interpretative approach employed by the court in all questions of statutory interpretation, however under a GAAR: ${ }^{104}$

... the analysis seeks to determine a different aspect of the statute than in other cases. In a traditional statutory interpretation approach the court applies the textual, contextual and purposive analysis to determine what the words of the statute mean. In a GAAR analysis the textual, contextual and purposive analysis is employed to determine the object, spirit or purpose of a provision. Here the meaning of the words may be clear enough.

${ }^{104}$ Copthorne above n 41 at [70] - [71]. 
The search for the rationale that underlies the words that may not be captured by the bare meaning of the words themselves. [Then], a court must consider whether the transaction falls within or frustrates the identified purpose.

Here, one can see how under s 245 extra factors can be taken into account to determine if the transaction abused the statute as a whole. $^{105}$ The Supreme Court of New Zealand has also emphasised the broad inquiry under s BG $1:^{106}$

The general anti-avoidance provision does not confine the Court as to the matters which may be taken into account when considering whether a tax avoidance arrangement exists. Hence the Commissioner and the courts may address a number of relevant factors, the significance of which will depend on the particular facts.

As mentioned, the Australian Part IVA lists a number of factors to consider when determining purpose, evidencing a clear legislative intention that the inquiry be broad in scope. It should be mentioned that the High Court in Consolidated Press Holdings affirmed that it is not necessary for a judge to refer to the matters in 177D individually, ${ }^{107}$ rather a global assessment of purpose is appropriate, and often an examination of the reasons set out in a judgment will show that relevant matters were taken into account. $^{108}$

Critics wary of the scope of a GAAR claim that the same limits that apply to a purposive approach similarly apply to a GAAR analysis, that is, it should not be used "to make a law

\footnotetext{
${ }^{105}$ Income Tax Act 1988 (Can) s 245

${ }^{106}$ Ben Nevis above n 31 at [108].

${ }^{107}$ Federal Commissioner of Taxation $v$ Consolidated Press Holdings Ltd (200

1) 207 CLR 235 at [94] affirming the approach of Hill J in Spotless above n 22.

${ }^{108}$ Ibid.
} 
consistent with Parliamentary intent if Parliament has failed to effectively state that intent in the statute."109 The classic feature of tax avoidance arrangements is that they technically satisfy the specific words of the law, as enacted by parliament. ${ }^{110}$ However, through enacting a GAAR, Parliament has expressed their intent. A clear intention to combat tax avoidance. As Woodhouse $\mathrm{P}$ provided in Challenge of the then GAAR s 99: ${ }^{111} 112$

"Be that as it may s 99 is obviously a central pillar of the income legislation (to use the language of the counsel for Challenge in accepting the fact) and a reflection of the firm and understandable conclusion of Parliament that there must be a weapon able to thwart technically correct but contrived transactions set up as a means of exploiting the Act for tax advantages."

In order to give effect to such a weapon, the courts have, and rightly so, invoked indicative factors to aid their determination.

\section{How the factors are used to draw the line}

Upon review of judicial approaches, it appears that each jurisdiction draws the line between mitigation and avoidance by reference to and use of denotative or suggestive factors. ${ }^{113}$ This paper proposes that these factors are at the core of each of the GAAR analyses, and that examining the use of them reveals that the substantive inquiry is essentially the same in each of our comparator jurisdictions. Examples of indicative factors include; artificiality, contrivance, pretence, undue complexity, the

\footnotetext{
${ }^{109}$ Kate Tokeley above $\mathrm{n} 61$ at [969].

${ }^{110}$ Challenge (PC) above $\mathrm{n} 58$ at [559]; and (CA) at [533]

${ }^{111}$ Income Tax Act 1976 (NZ) s 99 (repealed)

${ }^{112}$ Challenge (CA) above $\mathrm{n} 58$ at [532].

${ }^{113}$ See Triad Gestco Ltd v The Queen [2012] FCA 258; [2012] DTC 5156, 7385at [50]; and Ben Nevis above n 31 at [108]. Hart above n 22.
} 
relationships of the parties involved, and many more factors identified and considered by courts in GAAR cases.

Each jurisdiction uses the indicative factors at different stages of their GAAR analysis and to answer seemingly different questions. Canadian courts refer to factors to show an arrangement misuses provisions of the Act or is abusive. Australian courts use factors to conclude there is a dominant purpose of obtaining a tax benefit. In New Zealand, the courts refer to factors to show an arrangement was outside of parliament's contemplation. Yet, in each case the considering of factors gives judges the tool they need to go beyond the normal rules of statutory construction. ${ }^{114}$ In substance, they are always used as decisive tools to draw the line between avoidance and mitigation

Take the factor of 'undue complexity' for example. The courts in all three jurisdictions have used this factor to help determine whether tax avoidance exists.

In Hart Callinan $\mathrm{J}$ interpreted s 177D(b)(ii), which directs the court to the form and substance of the scheme, ${ }^{115}$ as requiring the court to ask, "whether the substance of the transaction (tax implications apart) could more conveniently, or commercially, or frugally have been achieved by a different transaction or form of transaction." "116 His Honour determined that it could, and used that factor, among others, to contribute to his finding of a dominant purpose, and in turn a finding of tax avoidance.

In Copthorne the Supreme Court of Canada held that a vertical amalgamation would have been the simpler course of

\footnotetext{
114 Judith Freedman, = Interpreting Tax Statutes: Tax Avoidance and the Intention of Parliament“ (2007) 123 Law Quarterly Review 53, 81; as cited in Atkinson above n 2. 
action, $^{117}$ and therefore concluded that the horizontal amalgamation was chosen because of the tax benefit. Although the text of the relevant provisions did not preclude a taxpayer from selecting the vertical option, ${ }^{118}$ Rothstein $\mathrm{J}$ determined that the choice of a horizontal amalgamation and its use here circumvented the words of the specific provisions, ${ }^{119}$ and frustrated and defeated the purpose of those provisions. ${ }^{120}$ In so finding, Rothstein $\mathrm{J}$ was able to conclude that the transactions were abusive, and accordingly avoidance per s 245 . $^{121}$

Finally, consider New Zealand's use of the undue complexity indicator. In BNZ Investments Wild J dedicated a section of his analysis to the matter of complexity and concluded that there was an unusual level of complexity involved for transactions that are in substance straightforward loans, as in $B N Z .^{122}$ In that case, complexity was one of many factors considered by Wild $\mathrm{J}$ in his application of the parliamentary contemplation test from Ben Nevis, and it contributed to his finding that the arrangements were not within parliaments contemplation, and were tax avoidance arrangements. $^{123}$

In each of these cases undue complexity was one of many factors referred to by the courts, but in each instance it was used to aid their determination of whether tax avoidance existed.

\section{Objection to considering factors when determining purpose}

The central criticism levied against considering factors when determining purpose is that the emphasis of a GAAR inquiry should not be on purpose. The argument goes; there is no

\footnotetext{
${ }^{117}$ Copthorne, above $\mathrm{n} 41$ at [37] and [62].

${ }^{118}$ At [126]

${ }^{119}$ At [124].

${ }^{120}$ At [125]-[126]-[127].

121 The court considered many other indicative factors, undue complexity being one of many. See the full judgment of Copthorne above $\mathrm{n} 41$ for other factors considered.

${ }^{122}$ BNZ Investments $v$ CIR (2009) 24 NZTC 23, 582 [BNZ Investments No 2

(HC)] at [281]-[284]

${ }^{123}$ See BNZ Investments above n 122 generally, and at [526]
} 
dichotomy between commercial and tax purposes - structuring to obtain a tax advantage is part of legitimate business and is itself an acceptable commercial purpose. However, through enacting a GAAR the legislature has indicated their view that, in certain circumstances, it is not an acceptable purpose. The courts now readily accept that in enacting a GAAR, parliament has expressed their intention to thwart contrived arrangements structured to gain tax advantages. ${ }^{124}$

The fact that parliament has expressed their intention is not the only way to rebut the objection here; that is, the objection to courts considering factors when determining purpose. Reviewing the substance of the inquiry in each jurisdiction reveals that when the courts give weight to certain factors they are embarking on essentially the same exercise, regardless of what element of the inquiry the court is addressing. The presence of artificiality or contrivance in an impugned arrangement can signal that there is a dominant purpose of obtaining a tax benefit, that the arrangement abuses the Act as a whole or that the arrangement used provisions in a manner outside of parliaments contemplation. The Supreme Court of New Zealand demonstrated this point well in Ben Nevis, where the same artificiality of the impugned arrangement was said to reveal tax avoidance was the 'primary if not the sole' purpose, ${ }^{125}$ and that the arrangement was not within parliaments purpose for the specific provisions. ${ }^{126}$

To further illustrate this point, consider the essential factor from Penny and Hooper: the artificially low setting of salaries. If a taxpayer set their salary artificially low to take advantage of a lower company tax bracket, that artificiality logically indicates that the taxpayer had a purpose of obtaining a tax advantage, that

\footnotetext{
${ }^{124}$ See for example, Penny and Hooper above n 58 at [47].

${ }^{125}$ Ben Nevis above n 31 at [122], note the merely incidental element of s BG 1 was not discussed in depth in Ben Nevis as it was not relied on by the appellants (see [114]), however the artificiality of the promissory note was still said to demonstrate a primary purpose of avoidance at [122].

${ }^{126}$ Ben Nevis above n 31 at [147] and [148]; and generally; see also [108].
} 
is why they accepted a lower salary. Identifying that artificiality also helps one conclude that the taxpayer has misused the provisions of the Act; by artificially decreasing my salary they are frustrating the object and purpose of the provisions which is to establish progressive tax rates and tax the reality of ones income. Finally as the court in Ben Nevis has outlined, it is not within Parliament's intention that specific provisions be used to gain a tax benefit in an artificial manner. ${ }^{127}$

The examples of undue complexity and artificiality evince that, while the questions are posed differently in each jurisdiction, the material inquiry is in essence the same; the indicative factors are used to aid the determination of whether tax avoidance exists, to draw the line between mitigation and avoidance.

\section{The Danger of Enumeration}

\section{A Factors - Should They Be Legislatively Enacted or Left to the Courts Discretion?}

Part IVA of Australia lists eight criteria to be considered by the courts. While not part of the comparison in this paper, it is noteworthy that South Africa, who had the benefit of learning from international experience, also chose to list indicative criteria (called tainted elements) in their GAAR when it was enacted in 2006. ${ }^{128}$ It seems the United Kingdom, upon reviewing international practice, similarly decided a legislated list of criteria was beneficial, and preferable to judicial discretion. ${ }^{129}$ The Canadian GAAR does not contain specifications other than the positive abuse requirement addressed above. The New Zealand GAAR is definitely the most broadly drafted of the four comparators, containing no listed criteria, and as such is subject

\footnotetext{
${ }^{127}$ Ben Nevis above n 31 at [108].

${ }^{128}$ Income Tax Act 58 of 1962 (S. Afr.) Part IIA s 80A - 80L.

${ }^{129}$ Finance Act 2013 (UK) s 207(20(a)-(c), 207(4)(a)-(c) and 207 (5). See also Aaronson Report above n 13 at [31]-[32] and the Illustrative GAAR at [42]-[54] and accompanying Guidance Note from [55].
} 
to some criticism for leaving too much in the hands of the court. $^{130}$

While enumerating a general anti-avoidance rule with lists of telling elements has the appearance of increasing certainty, ${ }^{131}$ enumeration is also dangerous for a GAAR, which, for its very role, needs to be broad. Enumerating a GAAR risks narrowing a rule that works best when drafted in general terms. ${ }^{132}$

\section{Objection to non-legislated factors:}

Essentially, the arguments in favour of listing factors in legislation are aimed at the ever-present concern about certainty. It seems logical to assert that, where certainty is an ultimate goal, a GAAR with a misuse requirement and with objective factors contained within the legislation is preferable to leaving scope for judicial discretion. ${ }^{133}$ Certainty, however, is not an unqualified

${ }_{130}$ Atkinson above n 2 at [44], [50] and [56]; G. T. Pagone "General Anti Avoidance Provisions in Australia and New Zealand" (paper presented to Society of Trust and Estate Practitioners New Zealand Trust Conference, Auckland, 30 March 2012).at [30]-[31] and [37] (writing extra-judicially). And see Sam Davies 'Seeking tax certainty: Is it time for a 'new' test for tax avoidance?' (29 July 2013) Buddle Findlay

$<$ http://www.buddlefindlay.com/article/2013/07/29/seeking-tax-certainty-is-ittime-for-a-new-test-for-tax-avoidance>.

131 John Prebble and Rebecca Prebble John Prebble and Rebecca Prebble "Chapter 4 Does the Use of General Anti Avoidance Rules to Combat Tax Avoidance Breach Principles of the Rule of Law?" Victoria University $<$ http://www.regulatorytoolkit.ac.nz/resources/papers/book-1/does-the-use-ofgeneral $>$ at [4.5.3].

${ }^{132}$ John Prebble John Prebble "Chapter 10 - General Anti-Avoidance Rules as Regulatory Rules of the Fiscal System: Suggestions for Improvement to the New Zealand Anti-Avoidance Rule" Victoria University < http://www.regulatorytoolkit.ac.nz/resources/papers/book-2/chapter-10general-anti-avoidance-rules-as-regulatory-rules-of-the-fiscal-systemsuggestions-for-improvements-to-the-new-zealand-general-anti-avoidancerule> at [10.1.3], see also Judith Freedman above n 12at [333] and [345][353], [354]-[357]; and generally, where Freedman proposes an anti-avoidance principle, arguably more broad than an un-enumerated rule. See also Judith Freedman above $n 24$ at [388]-[390].

${ }^{133}$ Atkinson above $\mathrm{n} 2$ at [54] 
good, ${ }^{134}$ and in some circumstances it should not be the overriding aim and is even undesirable. ${ }^{135}$ In any event, overspecification in the GAAR context does not necessarily produce certainty, or rather more certainty than a general rule, and in any case, over-specification is not desirable.

\section{Enumeration does not create more certainty.}

The concept that enumeration does not create more certainty is not a simple one, and to discuss it in depth is beyond the scope of this paper. At surface level, however, it can be explained. Take, for example, the above comparisons of the use of artificiality and undue complexity by Australian and New Zealand courts. The factors were used in both countries, in exactly the same way, to determine whether tax avoidance existed. If the substantive inquiry is the same, despite Part IVA being more detailed, it cannot be said that the application of the GAAR in Australia is more certain. For the rule is being applied in the same way, and the line is being drawn in more or less the same place.

Furthermore, neither factor (artificiality or undue complexity) is expressly enacted in s $177 \mathrm{D}(\mathrm{b})$ of Part IVA. However, the Australian courts still used them both to indicate an avoidance purpose and to determine that avoidance existed. ${ }^{136}$ If the courts will still always refer to those elements of an arrangement they consider relevant to their inquiry, and make logical conclusions by reference to the tainted elements they judge to be appropriate, enumeration arguably leads to less certainty. An Australian tax payer, who refers to the legislation before establishing a tax motivated scheme and relies on a literal and narrow construction of its terms, may find himself surprised when a judge conducts a broad inquiry and refers to elements not expressly enacted in s $177 \mathrm{D}$, but which that judge logically considers relevant to their inquiry.

\footnotetext{
${ }^{134}$ John Prebble and Rebecca Prebble above n 131 at [4.4] and preceding discussion.

135 Judith Freedman above n 12 at [333]

${ }^{136}$ See above discussion page 37-39.
} 
In the words of Professor Prebble, when explaining the broad scope of New Zealand's s BG 1, "Parliament has left these areas for the courts for very good reason. They are simply not amenable to detailed legislation."137

The next part of this paper focuses on the idea that enumeration is undesirable in the GAAR context. While specification may not even serve to achieve its goal of producing certainty, even if it did, fleshing out a GAAR is objectionable for other reasons.

\section{B Enumeration is Undesirable}

\section{Judicial Discretion is not so offensive as it seems:}

All four comparators in this paper are Common Law jurisdictions and as such are no strangers to judicially developed doctrines and principles. Many areas of commercial law involve vague or uncertain concepts which are applied by the courts to govern rights and obligations. ${ }^{138}$ The duty to act in good faith in contract law for example can override the literal language of a contract. ${ }^{139}$ Within tax law itself the concepts of income and capital are far from certain. ${ }^{140}$ A GAAR provision is not the only uncertain aspect of a legal system and not even of tax law. Yet it is subject to much criticism for its imprecise nature and for placing too much power in the hands of the court. ${ }^{141}$ In light of these considerations, it seems general anti-avoidance provisions are held to higher standards of certainty than other areas of law. ${ }^{142}$

\footnotetext{
${ }^{137}$ John Prebble above n 132 at [10.4.2]

138 Judith Freedman above n 12 at [346]. See also Kate Tokeley above n 61 at [966]. See also Weisbach above n 15 at [875]-[876].

${ }^{139}$ David Weisbach above n 15 at [884]-[885].

140 Judith Freedman above n 12 at [347].

141 Atkinson above n 2 at [44]; see also Tax Avoidance Working Group Improving the Operation of New Zealand's Tax Avoidance Laws (November 2011); and see Brian M Studniberg "Minding the Gap in Tax Interpretation: Does Specificity Oust the General Anti-Avoidance Rule Post-Copthorne” (2012) 38 Queen's Law Journal 209.

${ }^{142}$ Weisbach at above n 15.
} 
This inconsistency is likely attributable to the old view that taxpayers are free to construct their affairs to minimise tax, so long as they comply with the literal meaning of the law as enacted, ${ }^{143}$ and the creative compliance culture that in turn resulted. ${ }^{144}$ However, that view has long since been quashed. Statutory GAARs are express proof that parliaments reject this view. $^{145}$

Given that each of the comparators are jurisdictions that strive for strict adherence to the rule of law; any departure from its requirements, in this case certainty, must surely be considered necessary. The authors of "Does the Use of General AntiAvoidance Rules to Combat Tax Avoidance Breach the Rule of Law? A Comparative Study" concluded that the broad nature of a GAAR does indeed amount to a breach of the rule of law. ${ }^{146}$ However, the authors found the breach was justifiable, ${ }^{147}$ as it seems has each parliament who has enacted a statutory GAAR. Moreover, as a catch-all provision charged with the task of protecting the revenue gathering ability of the government its wide reach is important. As Prebble succinctly put it, highlighting the principle obstacle for any general anti-avoidance provision, creative compliance: "In order to respond to the many possible ways in which people can arrange their taxation and business, it is necessary to have a rule of very broad scope." ${ }^{148}$ Hence, it seems while a high level of uncertainty is involved in general anti-avoidance provisions, uncertainty in the law is not unheard of, and can be justified.

\footnotetext{
${ }^{143}$ Inland Revenue Commissioners v Duke of Westminster HL [1936] AC 1.; see also Alan Gunn “Tax Avoidance” (1978) 76 Mich L Rev 733, as cited in Weisbach above $n 15$ at [862] and accompanying text at [862].

${ }^{144}$ Weisbach above n 15 at [870]; see also Judith Freedman above n 24.

145 See for example the HMRC Guideline's, above n 90, express instruction that the Duke of Westminster principle is dead at [5].

146 Rebecca Prebble and John Prebble "Does the Use of General AntiAvoidance Rules to Combat Tax Avoidance Breach Principles of the Rule of Law?" 2 VUWLRP 8/2012 21.; and John Prebble above n 132 at [10.1.3].

${ }^{147}$ Rebecca Prebble and John Prebble above n 146 at [35]-[45].

${ }^{148}$ John Prebble above n 132 [10.1.3]
} 


\section{The Main Point: General anti-avoidance rules are broad on purpose.}

If one of the strengths of a general anti-avoidance rule is its indeterminacy and broad scope, attempting to make it more detailed seems counterproductive. ${ }^{149}$ As Woodhouse P explained of the New Zealand provision in Challenge: ${ }^{150}$

"There can be no doubt that when the provision was amplified and given its present statutory form by Parliament in 1974 the deliberate decision was then taken that, because the problem of definition in this elusive field could not be met by expressly spelling out a series of detailed specifications in the Statute itself, the interstices must be left for attention by the judges. Indeed during the legislative process of examining the proposed new section an amendment was proffered at the committee stage which might have given some added detail but was rejected as unacceptable."

The New Zealand Parliament has had numerous opportunities to add detail to the GAAR and has received much pressure to do so, ${ }^{151}$ yet on each occasion it has declined. ${ }^{152}$ The Australian Parliament, rather than amend

$\overline{149}$ John Prebble and Rebecca Prebble above n 131 at 4.5.5 and see generally John Prebble "Practical Problems from Publication of the Commissioner's Interpretation Guidelines" (Working Paper Series: Working Paper No. 8) < http://www.victoria.ac.nz/sacl/cagtr/workingpapers/WP08.pdf $>$.

${ }^{150}$ Challenge Corporation above $\mathrm{n} 58$ at [534]

${ }^{151}$ John Prebble above n 149 at [20] and John Prebble above n 132 at [10.4.1] speaking of the pressure even on the Commissioner to flesh out the general rule.

${ }^{152}$ John Prebble above n 149 at [20] and Rebecca and John Prebble above n 131 at [4.5.3] 
Part IVA to confine its scope, has chosen to act only to ensure its terms are applied broadly. ${ }^{153}$

\section{The Dangers of Enumeration:}

\section{Expressio Unius or Implied Exclusion}

Enacting lists of set criteria for the courts to consider risks important indicia being overlooked down the line, or too much weight being placed on those criteria so enacted. Expressio unius est exclusion alterius (the expression of one is the exclusion of others) may be an old rule of interpretation but it is far from dead. Rothstein $\mathrm{J}$ referenced the principle in Copthorne when he accepted the taxpayer's submission that a relevant defining provision in the statute was exhaustive. ${ }^{154}$ If a GAAR lists tainted elements and that list was found to be exhaustive, the scope of the GAAR would be significantly narrowed. Admittedly, there are protections against such an extreme conclusion. The United Kingdom GAAR for example expressly states that the lists of indicia are not intended to be exhaustive. ${ }^{155}$ Of similar effect, is the approach of the Australian courts in that they have not viewed the eight factors in s 177D(b) narrowly. ${ }^{156}$

However, the unconscious impact of legislated criteria can be more damaging. Short of holding a factor impliedly excluded from the inquiry, a court may place extra emphasis on expressly legislated criteria or let the criteria that have been enacted colour their entire approach. For example, while a court in the United

\footnotetext{
153 Tax Laws Amendment (Countering Tax Avoidance and Multinational Profit) Act 2013 (Cth) (Austl.) and see Tax Laws Amendment (Countering Tax Avoidance And Multinational Profit Sharing) Bill 2013 Explanatory Memorandum (Australia).

${ }^{154}$ Copthorne, above n 41 at [108] - [111].

${ }^{155}$ Finance Act 2013 (UK) s 207(6)

${ }^{156}$ s 177D(b) Income Assessment Act 1936 (Cth) (Austl); and see above at pages 37-39 where it was held in Hart that the form and substance factor from s $177 \mathrm{D}$ (b)(ii) was held to include an inquiry into not just whether the actual substance of the scheme matched the legal form but also whether the scheme could have been more frugally achieved by other means.
} 
Kingdom would acknowledge that the list of factors is not exhaustive, ${ }^{157}$ it may, even unintentionally, only consider other criteria which seem to be in the same class as the factors that are legislated. For example, while the High Court of Australia in Hart asked whether the scheme could have more frugally been achieved by other means, it justified asking that question by reference to one of the listed criteria. ${ }^{158}$

\section{Creative Compliance}

Creative compliance is an established practice in taxation. Every jurisdiction experiences it even when they have a GAAR. The formalistic and technical nature of tax law feeds creative compliance, as paths are drawn through detailed legislation. ${ }^{159}$ To enumerate and add specifications to the very rule aimed at countering creative compliance is inappropriate. As Freedman explains: ${ }^{160}$

When it comes to the distinction between tax avoidance [and mitigation] $\ldots$ the measure of 'certainty' achieved by formalism is not desirable since this leads to "creative compliance".

... [T] $]$ he production of ever more detailed rules simply encourages avoidance, or creative compliance, by the manipulation of those rules ... using the rules themselves as signposts as to how to achieve the effective avoidance. ... These observations result in the conclusion that what we need is not more precise and detailed avoidance provisions.

\footnotetext{
${ }^{157}$ As per s 207(6) Finance Act 2013.

158 See above n 120 and accompanying text.

${ }^{159}$ Doreen McBarnet and Christopher Whelan "The Elusive Spirit of the Law: Formalism and the Struggle for Legal Control" (1991) 54 The Modern Law Review 848, at [848], [849] and generally; see also John Braithwaite "Rules and Principles: A Theory of Legal Certainty" (2002) 27 Australian Journal of Legal Philosophy 47, at [53] and [57].

${ }^{160}$ Freedman above $\mathrm{n} 12$ at [346].
} 
Freedman concludes from her observations about creative compliance that what is not needed is more precise and detailed avoidance provisions. ${ }^{161}$

This paper agrees with that proposition. A gear provides direction to the court by demonstrating a clear intention that Parliament wishes to counter tax avoidance. A broadly drafted rule ensures all arrangements are capable of being subject to the gear. Moreover a broad rule does not open itself up to abuse and manipulation which can undermine its operation.

A government cannot predict every arrangement or situation when it comes to the sophisticated and technical world of tax but what they can do is enact a broad rule, with a clear function of countering tax avoidance to foster a broad judicial approach and enable the courts use of indicative factors not normally resorted to in mere purposive interpretation. The following final example reveals the unfortunate complications Australia has faced as a result of adding detail to their Part IVA.

\section{Enumeration Gone Wrong - Identifying a Counterfactual}

The Australian experience with general anti-avoidance provisions provides an unfortunate but excellent example of the danger of adding detail in the GAAR context. Enumeration and specifications have seen the GAAR in Australia be bogged down by arbitrary litigation and lines of argument that effectively emasculate its terms. Australia's current gear was a response to a judicial attitude that had rendered the old s 260 almost useless. ${ }^{162}$ This background contributed to the decision by Parliament to add

\footnotetext{
${ }^{161}$ Judith Freedman above n 12 at [353].

162 John Prebble and Rebecca Prebble above n 131 at [4.2.5] and [4.5.3] and see Christine Barron, General Manager of Corporate and International Tax Division, Australian Treasury, "Anti-Avoidance Rules in Taxation: Striking a Balance" (speech to the Asian Tax Authorities Symposium, Kuala Lumpur, 4 September 2012)
} 
detail to the terms of Part IVA, in the hope that a clear legislative intent expressed in precise rules would not be able to be read down as its predecessor was. However while detailed terms have the appearance of adding certainty and direction, they also add complexity and open up the provision to arbitrary litigation.

The first serious debate concerning the operation of Part IVA concerned the role of the scheme identified by the Commissioner. ${ }^{163}$ Part IVA requires the dominant purpose was to obtain the tax benefit in connection with the scheme. ${ }^{164}$ The Full Court in Peabody found that, because the Commissioner had identified the scheme widely, the dominant purpose of the wider scheme was of a commercial nature and was not to enable the taxpayer to obtain a tax benefit. ${ }^{165}$ The Commissioner responded arguing that the provisions of Part IVA do not only cover a scheme but any part of a scheme, ${ }^{166}$ hence if the taxpayer's dominant purpose for part of the scheme was to obtain a tax benefit then it was within the meaning of Part IVA. ${ }^{167}$ The High Court did not agree that a scheme under Part IVA included part of a scheme and any circumstances incapable of standing on their own without being 'robbed of all practical meaning' would not constitute a scheme under Part IVA. ${ }^{168}$ That passage provided the foundation for later arguments that circumstances identified by the Commissioner as schemes could not be subject to Part IVA if they were incapable of standing on their own without being robbed of all practical meaning. ${ }^{169}$ Ten years later in Hart, their Honours explained that it was an error to treat the comments from Peabody as "a criterion which must be applied in deciding whether there is a scheme to which Part IVA applies." Now the

\footnotetext{
${ }^{163}$ Pagone above n 130 at [14].

164 s 177A(5) Income Tax Assessment Act 1936 (Cth) (Austl) (emphasis added).

${ }^{165}$ Federal Commissioner of Taxation v Peabody (1994) 181 CLR 359. (HC) at [383].

${ }^{166}$ Relying on s 177A(5) and 177D Income Tax Assessment Act (cth) (Austl) see Peabody above n 165 at [383].

${ }^{167}$ Peabody above n 165 at [383].

${ }^{168}$ Peabody above n 165 at [384]-[385].

${ }^{169}$ Pagone above n 130 at [16].
} 
Commissioner in Australia may identify a scheme very narrowly to overcome the dominant purpose requirement. In this way, the identification of a scheme by the Commissioner has lost some of its significance but as Pagone stated, writing extra-judicially, "the effect of Peabody was not without cost and uncertainty."170

Another, arguably more serious example of the effects of a detailed gear is the Australian approach to identifying a tax benefit.. Section $177 \mathrm{C}$ sets out when a tax benefit is be subject to Part IVA. The relevant part of the provision provides: ${ }^{171}$

(1) Subject to this section, a reference in this Part to the obtaining by a taxpayer of a tax benefit in connection with a scheme shall be read as a reference to:

(a) an amount not being included in the assessable income of the taxpayer of a year of income where that amount would have been included, or might reasonably be expected to have been included, in the assessable income of the taxpayer of that year of income if the scheme had not been entered into or carried out;

Section 177 (b), (ba), (bb) and (bc) are similar paragraphs concerning deductions, capital loss, foreign income tax offset and withholding tax, however it is the italicised words that are important for the purposes of this part. Those words have been said to require a consideration of what the scheme produced and a comparison with an alternative postulate, or counterfactual. ${ }^{172}$ Indeed, the Australian government has said that the Part IVA inquiry implicitly requires a comparison between the scheme in question and an alternative postulate. ${ }^{173}$

\footnotetext{
${ }^{170}$ Pagone above $\mathrm{n} 130$ at [16].

171 Part IVA s 177C(1)(a) Income Tax Assessment Act 1936 (Cth) (Austl) (emphasis added).

172 Pagone above n 130 Hart at [66].

173 Tax Laws Amendment (Countering Tax Avoidance And Multinational Profit Sharing) Bill 2013 Explanatory Memorandum (Australia).
} 
At first instance the need to consider a comparison does not seem extraordinary, or indeed harmful. It seems logical that a comparison sometimes be used under a GAAR analysis, as the Supreme Court of Canada explained in Canada Trustco: ${ }^{174}$

If a deduction against taxable income is claimed, the existence of a tax benefit is clear, since a deduction results in a reduction of tax. In some other instances, it may be that the existence of a tax benefit can only be established by comparison with an alternative arrangement. For example characterization of an amount as an annuity rather than as a wage, or as a capital gain rather than as business income, will result in differential tax treatment.

The Canadian courts often identify a tax benefit by comparing the impugned transaction to what 'might reasonably have been carried out but for the existence of the tax benefit, 175 such a comparison contributes not only to a finding of a tax benefit but also a purpose of obtaining that benefit and even whether there was an abuse of the Act.

As discussed above, in Copthorne the Supreme Court of Canada considered that a vertical amalgamation would have been simpler. The taxpayer in that case argued that they would never have chosen a vertical amalgamation because of the higher liability to tax, which made it an unreasonable choice, and thus there was no tax benefit. The Court held, however, that, but for the difference in tax, a vertical amalgamation was a reasonable option, ${ }^{176}$ emphasising that a vertical amalgamation would have produced the same non-tax consequences and benefits. ${ }^{177}$ As the use of a vertical amalgamation frustrated the purpose of the

\footnotetext{
${ }^{174}$ Canada Trustco above n 39 at [20].

175 Copthorne above n 41; Canada Trustco above n 39 at [20]; and Canadian Pacific Ltd v The Queen 2000 DTC 2428 [2001] 1 CTC 2190 (TCC).

${ }^{176}$ Copthorne above n 41 per Rothstein J at [37].

${ }^{177}$ Copthorne above $\mathrm{n} 41$ per Rothstein J at [62].
} 
specific provisions, the court found the transaction was abusive avoidance, ${ }^{178}$ and concluded the Commissioner's reassessment of liability to tax based on a horizontal amalgamation was correct.

Historically, the counterfactual element of the Part IVA inquiry has proceeded similarly to the example from Copthorne. The proposed counterfactual was based on the idea that the taxpayer would have done something other than the impugned transaction in order to achieve a similar business outcome. ${ }^{179}$ That is, tax implications apart, the results of the transactions were considered part of what the hypothetical postulate must produce. $^{180}$

However, in a number of cases from the early 2010's taxpayers argued successfully that they did not obtain a tax benefit at all, ${ }^{181}$ because without the scheme they would not have entered into an arrangement that attracted tax. ${ }^{182}$ Rather, they would have entered into another scheme that avoided tax, or they would have done nothing at all. ${ }^{183}$ In RCI Pty Ltd the Australian Full Court accepted the argument that a company would not have disposed of its shares if it had had to pay tax on the transaction. That is, it would not have done anything. As no tax would have been payable on maintaining ownership of the shares, there was no tax benefit from the arrangement that did not occur. ${ }^{184}$ In this

\footnotetext{
${ }^{178}$ Copthorne above $\mathrm{n} 41$ at [124] - [127]

179 Christine Barron, General Manager of Corporate and International Tax Division, Australian Treasury, "Anti-Avoidance Rules in Taxation: Striking a Balance" (speech to the Asian Tax Authorities Symposium, Kuala Lumpur, 4 September 2012), see for example Hart above n 22, Spotless above n 22 and Peabody above n 165.

${ }^{180}$ Barron above n 179 and Tax Laws Amendment (Countering Tax Avoidance And Multinational Profit Sharing) Bill 2013 Explanatory Memorandum (Australia).

${ }^{181}$ RCI Pty Ltd v Federal Commissioner of Taxation [2011] FCAFC 104; and Commissioner of Taxation v Futuris Corporation Ltd [2012] FCAFC 32

182 Barron above n 179 and Explanatory Memorandum above n 180.

${ }^{183}$ Barron above n 179.

${ }^{184}$ RCI Pty Ltd above n 181 and Barron above n 179.
} 
way, it was not held to be necessary that the counterfactual scenario produce any of the other business outcomes of the impugned scheme.

Such an approach could potentially undermine the effectiveness of Part IVA entirely. In response the Government has had to amend Part IVA to ensure an alternative postulate comprises existing facts and circumstances minus the tax scheme itself, ${ }^{185}$ to ensure that when determining whether a counterfactual is a reasonable alternative regard should be had to the substance of the scheme and not to the tax cost of the scheme or to the tax consequences of the counterfactual. This complication is almost wholly attributable to the detailed form of Part IVA. In adding seemingly harmless words such as 'would have been or might reasonably be expected to have been ... had the scheme not been entered into or carried out' the Australian government opened Part IVA up to circumvention. The counterfactual experience of Australia is a prime example of over specification leading ultimately to complication and a narrowing of the scope of a GAAR.

${ }^{185}$ Explanatory Memorandum above n 180. 


\section{Conclusion}

This paper examines the proposition that general anti-avoidance rules achieve their purpose better when drafted in broad terms. Several jurisdictions have included misuse and abuse requirements in their GAARs in order to provide certainty and a high threshold for the GAAR's operation. Others have enumerated their GAAR to add precision and certainty to its terms. Notably, the United Kingdom after watching other jurisdictions deal with their general anti avoidance provisions for decades chose to do both, that is to include a misuse/abuse requirement and to add detail to their gear through the inclusion of legislated indicative factors.

While misuse and abuse requirements and enumeration have the appearance of adding precision to an uncertain area of law, in practice this is doubtful. The general anti-avoidance provisions of four jurisdictions were compared, namely Australia, Canada, New Zealand and the United Kingdom. The comparison of approaches undertaken by each of the Canadian and New Zealand courts revealed that the inquiry was materially the same. Interestingly, Oxford dictionary defines misuse as the use of something "in the wrong way or for the wrong purpose". At the risk of oversimplification, is it not essentially the same thing to ask whether an arrangement misuses provisions as to ask whether an arrangement uses a provision for an unintended purpose? Finally this paper compared GAARs of the broad spectrum (for example Canada and New Zealand's) to Australia's more detailed provision, and found that the detail added to Part IVA in an attempt to create certainty, did not transform the fundamental inquiry of the courts and rather brought undesirable complexity to an already complex area of law, creating arbitrary litigation and ultimately serving to undermine the provision.

The comparisons in this paper served to demonstrate two central points, which in turn both contribute to one main proposition. 
1 An abuse/misuse requirement does not fundamentally alter the material inquiry under a GAAR.

2 Adding detail to a GAAR also does not fundamentally alter the inquiry and actually does more harm than good.

These two points, made by way of comparison, both contribute to the central proposition of this paper that GAARs work best when drafted in broad terms. 


\section{BIBLIOGRAPHY}

\section{BIBLIOGRAPHY}

A. Cases

a. New Zealand

Alesco New Zealand Limited and Ors v Commissioner of Inland Revenue [2013] NZCA 40

Ben Nevis Forestry Ventures Ltd v Commissioner of Inland Revenue [2008] NZSC 115, [2009] 2 NZLR 289 ('Ben Nevis')

$B N Z$ Investments $v$ CIR (2009) 24 NZTC 23, 582 [BNZ Investments No 2 (HC)]

CIR v Challenge Corporation Ltd [1986] 2 NZLR 513 (PC); [1986] 2 NZLR 513 (CA)

Commissioner of Inland Revenue v Auckland Harbour Board [2001] 3 NZLR 289 (PC).

Commissioner of Inland Revenue v BNZ Investments Ltd [2002] 1 NZLR 450 (CA) [BNZ Investments No 1 (CA)]

Commissioner of Inland Revenue v Europa Oil (NZ) Ltd [1971] NZLR 641

Elmiger and Another v Commissioner of Inland Revenue [1966] NZLR 683

Glenharrow Holdings Ltd v Commissioner of Inland Revenue [2008] NZSC 116, [2006] 2 NZLR 359

Hadlee and Sydney Bridge Nominees Ltd $v$ Commissioner of Inland Revenue (1993) 15 NZTC 10, 106 (PC); [1991] 3 NZLR 517 (CA); [1989] 2 NZLR 447 (HC)

Mangin v Commissioner of Inland Revenue [1971] NZLR 591 (PC)

Penny v Commissioner of Inland Revenue [2011] NZSC 95, [2012] 1 NZLR 433; [2010] NZCA 231, [2010] 3 NZLR 360 (litigation known as Penny and Hooper)

Westpac Banking Corporation v Commissioner of Inland Revenue [2009] NZCA 24.

\section{b. United Kingdom}

Barclays Mercantile Business Finance Limited v Mawson (Inspector of Tax) [2004] UKHL 51; STC 1

Furniss (Inspector of Taxes) v Dawson [1984] AC 474 (HL)

Inland Revenue Commissioners v Duke of Westminster HL [1936] AC 1.

IRC v McGuckian [1997] 1 WLR 991

Jones v Garnett [2007] UKHL 35; [2005] EWCA 1553; [2005]

EWHC 849 (Ch)

MacNiven (HM Inspector of Taxes) $v$ Westmoreland Investments Ltd [2001] UKHL 6, [2003] 1 AC 311

$W$ T Ramsay Ltd v Inland Revenue Commissioners [1982] AC 300

(HL) 


\section{c. Australia}

Anderson v Commissioner of Taxes (Vic) (1937) 57 CLR 233

Austin v The Commonwealth (2003) 51 ATR 654

Cridland v FCT [1977] HCA 61

Federal Commissioner of Taxation v Consolidated Press Holdings Lt d (2001) 207 CLR 235.

Federal Commissioner of Taxation v Hart [2004] HCA 26; 217 CLR 216

Federal Commissioner of Taxation v Peabody (1994) 181 CLR 359.

Federal Commissioner of Taxation v Spotless Services Ltd [1996]

HCA 34; (1996) 186 CLR 404.

Mills $v$ of $T$ [2012] HCA 51

Mullens v Federal Commissioner of Taxation [1976] HCA 47; (1976)

135 CLR 290

Newton v Federal Commissioner of Taxation (1958) 98 CLR 1, 7

(PC); (1956) 96 CLR 577 (HC)

W P Keighery Pty Ltd v FCT [1957] HCA 2; (1957) 100 CLR 66

\section{d. Canada}

1207192 Ontario Ltd $v$ The Queen 2012 FCA 259

65302 British Columbia Ltd v Canada [1999] 3 SCR 804, [2000] 1

CTC 57 (SCC)

Canada Trustco Mortgage Co v Canada (2005) SCC 54.

Copthorne Holdings Ltd v Canada 2011 SCC 63, [2011] 3 SCR 721.

Lipson v The Queen (2009) DTC 5528, [2009] SCC 1

The Queen v Global Equity Fund 2012 FCA 272

Stubart Investments Ltd v The Queen [1984] CTC 294, 84 DTC 6305; [1984] 1 SCR 536 (SCC)

Triad Gestco Ltd v The Queen [2012] FCA 258; [2012] DTC 5156, 7385

\section{e. India}

Vodafone International Holdings B.V.v Union of India Civil [2012]

341 ITR 1 (SC)

\section{B. Legislation}

\section{a. New Zealand}

Income Tax Act 2007 (NZ)

Interpretation Act 1999 (NZ)

Tax Administration Act 1994 (NZ)

b. United Kingdom

Finance Act 2004 (UK)

Finance Act 2013 (UK)

Finance Bill (2013)

Income and Corporation Taxes Act 1988 (UK)

Income Tax Act 2007 (UK)

Income Tax (Trading and Other Income) Act 2005 (UK)

c. Australia

Acts Interpretation Act 1901 (Cth) (Austl.)

Income Tax Assessment Act 1936 (Austl.) 
Tax Administration Act 1994 (Austl.)

Taxation (Unpaid Company Tax) Assessment Act 1982

(Cth) (Austl.)

Crimes (Taxation Offences) Act 1980 (Cth)

d. Canada

Income Tax Act RSC 1985, c. 1 ( $5^{\text {th }}$ Supp.) as amended (Can.)

e. South Africa

Income Tax Act No 58 of 1962 (S. Afr.)

f. Hong Kong

Inland Revenue Ordinance (HK)

\section{Bills, Explanatory Memoranda And Guidelines}

HM Revenue and Customs (HMRC's GAAR Guidance) (15 April 2013) (United Kingdom).

Tax Laws Amendment (Countering Tax Avoidance And Multinational Profit Sharing) Bill 2013 Explanatory Memorandum (Australia).

\section{Books, and Chapters in Books}

Judith Freedman (ed) Beyond Boundaries: Developing Approaches to Tax Avoidance and Tax Risk Management (Oxford University Centre for Business Taxation, UK, 2008).

Grabosky, P, Braithwaite, J Trends \& Issues in Crime and Criminal Justice No. 5, Corporate crime in Australia (Australian Institute of Criminology, Canberra, 1987)

Bryan A. Gardner (ed) Black's Law Dictionary ( ${ }^{\text {th }}$ ed, West, 2009)

Friedrich A Hayek The Constitution of Liberty (Routledge, London, 1960).

Michael Littlewood "Tax Avoidance, the Rule of Law and The New Zealand Supreme Court" in Richard Ekins (ed) Modern Challenges to the Rule of Law (LexisNexis NZ, Wellington, 2011) 263.

Chris Wales (ed) fair tax: towards a modern system (The Smith Institute, London, 2008).

\section{E. Journal Articles}

Brian J Arnold "Reflections on the Relationship Between Statutory Interpretation and Tax Avoidance" (2001) 49 Canadian Tax Journal 1.

Chris Atkinson "General Anti-Avoidance Rules: Exploring the Balance Between the Taxpayer's Need For Certainty and the 
Government's Need to Prevent Tax Avoidance" (2012) 14 Journal of Australian Taxation 1.

Doreen McBarnet and Christopher Whelan "The Elusive Spirit of the Law: Formalism and the Struggle for Legal Control" (1991) 54 The Modern Law Review 848,

Valerie Braithwaite, Kristin Murphy, and Monika Reinhart "Taxation Threat, Motivational Postures and Responsive Regulation" (2007) 29 Law \& Policy 137.

Thomas Carothers "The Rule of Law Revival" (1998) 77 Foreign Aff. 95.

Julie Cassidy “Part IVA - A Toothless Tiger?” (2001) 11 Revenue LJ 65.

Julie Cassidy "'To GAAR or not to GAAR - that is the question:" Canadian and Australian Attempts to Combat Tax Avoidance" (2006) 36 Ottawa Law Review 261.

Charles W Cope and Vikas Vasal "On the Vodafone Roller Coaster: India's Supreme Court Provides Multinationals a Short-Lived Solace" (2012) 41 TMIJ 179.

Jo Cleary "The Evolution of Tax Avoidance" (1995) 5 Revenue Law Journal 219.

Richard Edmonds “A Judicial Perspective on Tax Reform” (2011) 35 Melbourne University Law Review 236.

Judith Freedman "Converging Tracks? Recent Developments in Canadian and UK Approaches to Tax Avoidance" (2005) 53 Canadian tax Journal 1038.

Judith Freedman "Defining Taxpayer Responsibility: In Support of a General Anti-Avoidance Principle” (2004) 4 BTR 332.

Judith Freedman "Improving (Not Perfecting) Tax Legislation: Rules and Principles Revisited” (2010) 6 British Tax Review 717.

Judith Freedman "Tax and Corporate Responsibility" (2003) 695 Tax Journal 2.

Judith Freedman "The Tax Avoidance Culture: Who Is Responsible? Governmental Influences and Corporate Social responsibility" in Jane Holder and Colm O'Cinneide (eds) Current Legal Problems 2006 (Oxford University Press, 2007) 359. 
Lord Hoffman, "Tax Avoidance” (2005) British Tax Review 197, 204 CHECK

Jinyan Li "“"Economic Substance": Drawing the Line Between Legitimate Tax Minimization and Abusive Tax Avoidance" (2006) 54 Canadian Tax Journal 23.

John McLaren "The Distinction Between Tax Avoidance and Tax Evasion has become blurred in Australia: Why has it happened? (2008) 3 Journal of the Australian Tax Teachers Association 141.

Michael Littlewood "The Privy Council and the Australasian AntiAvoidance Rules” (2007) 2 British tax Review 175.

John Prebble and Zoe Prebble "Comparing the General AntiAvoidance Rule of Income Tax Law with the Civil Law Doctrine of Abuse of Law" (2008) Bulletin for International Taxation 151.

John Prebble and Zoe Prebble "The Morality of Tax Avoidance" (2010) 20 Creighton Law Review 101.

Rebecca Prebble and John Prebble "Does the Use of General AntiAvoidance Rules to Combat Tax Avoidance Breach Principles of the Rule of Law?” 2 VUWLRP 8/2012 21.

Brian M Studniberg "Minding the Gap in Tax Interpretation: Does Specificity Oust the General Anti-Avoidance Rule Post-Copthorne" (2012) 38 Queen's Law Journal 209.

Kate Tokeley "Interpretation of Legislation: Trends in Statutory Interpretation and the Judicial Process" (2002) 33 VUWLR 965.

David A Weisbach "Formalism in the Tax Law" (1999) 66 The University of Chicago Law Review 860.

Lidia Xynas "Tax Planning, Avoidance and Evasion in Australia 1970-2012: The Regulatory Responses and Taxpayer Compliance" (2011) 20 Revenue Law Journal 1.

Lawrence Zelenak "Codifying Anti-Avoidance Doctrines and Controlling Corporate Tax Shelters" (2001) 54 SMU Law Review 177.

\section{F. Papers and Reports}


Graham Aaronson QC GAAR Study (11 November 2011).

KW Asprey and Ross Parsons, Chapter 11 - Income Splitting (Taxation Review Committee 1975, University of Sydney Library 2001).

Australian Tax Office Compliance Program 2009-2010 (2010), $<\mathrm{http}: / /$ www.ato.gov.au/corporate/content.asp?doc $=/$ content $/ 0020543$ $5 . h t m \& m n u=47063 \& m f p=00>$.

Australian Taxation Office, Stepping into the Shoes of Small Business - A Review of the Small Business Market (1996), < http://www.ato.gov.au>

Michael D'Ascenzo, the then Commissioner for Taxation, Australian Taxation Office ATO Examining Takeover Arrangements (2010) $<$ http://www.ato.gov.au/corporate/content.asp?doc=/content/0023179 5.htm>,

Draft Comprehensive Guideline to the General Anti Avoidance Rule (Legal and Policy Division South African revenue Service, 2006)

John Howard Income Tax Laws Amendment Bill (no. 2) 1981

Explanatory Memorandum (?????????????????

HM Revenue and Customs HMRC's GAAR Guidance (April 2013).

ICC Commission on Taxation Application of Anti-Avoidance Rules in the field of taxation (International Chamber of Commerce, Policy Statement No. 180/519, January 2012).

Information Circular: General Anti Avoidance Rule Section 245 of the Income Tax Act (Revenue Canada, Taxation, 88-2, 21 October 1988).

Interpretation Statement: Tax Avoidance and the Interpretation of Sections BG 1 and GA 1 of the Income Tax Act 2007 (Public Rulings Unit, Office of the Chief Tax Counsel, 13 June 2013)

OECD Secretary-General Report to the G20 Leaders (OECD, St Petersburg, 5-6 September 2013)

OECD Taxpayer's Rights and Obligations: A Survey of the Legal Situation in the OECD Countries (OECD, 1990) at [2.21].

Review of Business Taxation A Platform for Consultation Discussion Paper 2: Building on a strong foundation (February 1999) $<$ http://www.rbt.treasury.gov.au/publications/paper3/download/Ch24. $\mathrm{PDF}>$. 
Steve Bond, Malcolm Gammie and John Whiting "Tax Avoidance" (Chapter 10) in Robert Chote, Carl Emmerson, Rupert Harrison and David Miles (eds) The IFS Green Budget: January 2006 (IFS, ISBN: 978-1-903274-44-6, January 2006).

Antony Seely Tax Avoidance: a General Anti-Abuse Rules (Business and Transport Section, House of Commons, SN6265, 9 May 2013) at [1].

Tax Avoidance Working Group Improving the Operation of New Zealand's Tax Avoidance Laws (November 2011).

(Prepared by;) Taxation Committee of the New Zealand Law Society, the Corporate Taxpayers Group, and the Taxation Committee of the New Zealand Institute of Chartered Accountants Improving the Operation of New Zealand's Tax Avoidance Laws (October 2011) $<$ http://docs.business.auckland.ac.nz/Doc/improving-the-operationof-nz-tax-avoidance-laws-2248668.pdf>.

Honourable Michael H Wilson The Explanatory Notes to Legislation Relating to Income Tax (Ministry of Finance, June 1988) at [461].

\section{G. Unpublished Texts}

\section{a. Papers Presented to Conferences}

John Christensen, Pete Coleman and Sony Kapoor "Tax Avoidance, Tax Competition and Globilisation: making tax justice a focus for global activism" (paper presented to the Global Tax Workshop, Finland, November, 2004).

G. T. Pagone "General Anti Avoidance Provisions in Australia and New Zealand" (paper presented to Society of Trust and Estate Practitioners New Zealand Trust Conference, Auckland, 30 March 2012).

\section{b. Working Papers}

David Dunbar "Judicial Techniques for Controlling the New Zealand General Anti-Avoidance Rule: A Case of Old Wine in New Bottles, from Challenge Corporation to Peterson" (School of Accounting and Commercial Law, Victoria University of Wellington Working Paper Series, Paper no. 38, 2005)

Graeme Cooper "Predicting the Past - the Problem of Finding a Counterfactual in Part IVA" (Legal Studies Research Paper No. 11/49, Sydney Law School, August 2011). 
Judith Freedman, Geoffrey Loomer and John Vella "Corporate Tax Risk and Tax Avoidance: New Approaches" (Legal Research Paper Series, Paper no. 13/2009, April 2009).

John Prebble "Practical Problems from Publication of the Commissioner's Interpretation Guidelines" (Working Paper Series: $\begin{array}{lllll}\text { Working } & \text { Paper } & \text { No. } & 8)\end{array}$ http://www.victoria.ac.nz/sacl/cagtr/working-papers/WP08.pdf>.

David F Williams "Developing the Concept of Tax Governance" (February 2007) KPMG's Tax Business School $<$ http://www.kpmg.co.uk/pubs/?PubID=1939\&m1=1>

\section{c. Theses}

Benedict Charles Prebble "Should Tax Avoidance be Criminalised? Tax Avoidance and Criminal Law Theory" (LLB (Hons) Dissertation, University of Otago, 2011).

Ling Zhang "Tax Avoidance: Causes and Solutions" (MBA Thesis, University of Auckland, 2007).

\section{H. Internet Resources}

James Bailey "Arctic Systems - the Good News and the Bad News!" (August 2007) Tax Insider < http://www.taxinsider.co.uk/231Arctic_Systems_the_Good_News_and_the_Bad_News.html $>$

Andrew Babbage "Penny and Hooper - tax avoidance - what questions have been answered?" (2011) Deloitte $<$ http://www.deloitte.com/view/en_nz/nz/63b268c391222310VgnVC M3000001c56f00aRCRD.htm>

"GAAR rising Mapping tax enforcement's evolution" (February 2013) Ernst \& Young $<$ http://www.ey.com/Publication/vwLUAssets/GAA_rising/\$FILE/G AAR_rising_1\%20Feb_2013.pdf $>$

David Goldberg "The Approach of the Acourts to Tax Planning Schemes" Taxbar $<$ http://www.taxbar.com/documents/Approach_Courts_David_Goldb erg.pdf $>$

P N Grabosky, 'Wayward governance: illegality and its control in the public sector' (1989) Australian Institute of Criminology, 143 
$<$ http://aic.gov.au/en/publications/previous\%20series/lcj/120/waywar $\mathrm{d} / \operatorname{ch} 9 \mathrm{t} \cdot \mathrm{asx}>$

"General Anti-Avoidance Rules India and International perspective" Deloitte $<\mathrm{http}: / /$ www.deloitte.com/assets/DcomIndia/Local\%20Assets/Documents/Tax\%20documents/GAAR\%20\%20India\%20and\%20International\%20Perspective.pdf $>$

Inland Revenue Department "Compliance: Tax schemes and aggressive tax planning" (27 July 2011) Inland Revenue $<$ http://www.ird.govt.nz/taxagents/compliance/news/archive/complia nce-news-atp.html>

"Jones v Garnett - House of Lords decision" (July 2007) Chartered Accountants \& Business Advisers

$<$ http://www.cfwaccountants.co.uk/accountancy_info.php?article=31 $6 \&$ name $=$ Jones $>$

Casey Plunket "Keep a steady focus on what BG 1 says: Penny \& Hooper V CIR" (2011) my.lawsociety $<$ http://my.lawsociety.org.nz/in-practice/the-changing-law/casecommentary/keep-a-steady-focus-on-what-bg-1-says-penny-andhooper-v-cir>

John Prebble "Chapter 10 - General Anti-Avoidance Rules as Regulatory Rules of the Fiscal System: Suggestions for Improvement to the New Zealand Anti-Avoidance Rule" Victoria University < http://www.regulatorytoolkit.ac.nz/resources/papers/book-2/chapter10-general-anti-avoidance-rules-as-regulatory-rules-of-the-fiscalsystem-suggestions-for-improvements-to-the-new-zealand-generalanti-avoidance-rule>

John Prebble and Rebecca Prebble "Chapter 4 Does the Use of General Anti Avoidance Rules to Combat Tax Avoidance Breach Principles of the Rule of Law?" Victoria University $<$ http://www.regulatorytoolkit.ac.nz/resources/papers/book-1/doesthe-use-of-general>

Peter Stevens "Analysis The Changing Limits of Acceptable Tax Avoidance" (11 January 2013) Tax Journal $<$ http://www.taxjournal.com/tj/articles/changing-limits-acceptabletax-avoidance-11012013> 
"Tax avoidance schemes 'utterly immoral' says Hodge" $B B C$ News (online ed. UK, 6 December 2012) $<$ http://www.bbc.co.uk/news/business-20624848>

"Tax Controversy and Dispute Resolution Alert: General antiavoidance rules: What are the key elements to a balanced approach?" (4 June 2012) PWC

$<$ http://www.publications.pwc.com/DisplayFile.aspx?Attachmentid= 5747\&Mailinstanceid $=24703>$

$<$ http://www.ukuncut.org.uk/targets>,

\section{Speeches}

Christine Barron, General Manager of Corporate and International Tax Division, Australian Treasury, "Anti-Avoidance Rules in Taxation: Striking a Balance" (speech to the Asian Tax Authorities Symposium, Kuala Lumpur, 4 September 2012) 